\title{
Estimation of cloud condensation nuclei number concentrations and comparison to in situ and lidar observations during the HOPE experiments
}

\author{
Christa Genz $^{1, a, i}$, Roland Schrödner ${ }^{1}$, Bernd Heinold ${ }^{1}$, Silvia Henning ${ }^{1}$, Holger Baars ${ }^{1}$, Gerald Spindler ${ }^{1}$, and \\ Ina Tegen ${ }^{1}$ \\ ${ }^{1}$ Leibniz Institute for Tropospheric Research (TROPOS), Permoserstraße 15, 04318 Leipzig, Germany \\ ${ }^{a}$ now at: German Centre for Integrative Biodiversity Research (iDiv) Halle-Jena-Leipzig, \\ Deutscher Platz 5e, 04317 Leipzig, Germany \\ i previously published under the name Christa Engler
}

Correspondence: Christa Genz (christa.genz@idiv.de)

Received: 27 August 2019 - Discussion started: 17 September 2019

Revised: 8 June 2020 - Accepted: 16 June 2020 - Published: 24 July 2020

\begin{abstract}
Atmospheric aerosol particles are the precondition for the formation of cloud droplets and therefore have large influence on the microphysical and radiative properties of clouds. In this work, four different methods to derive or measure number concentrations of cloud condensation nuclei $(\mathrm{CCN})$ were analyzed and compared for presentday aerosol conditions: (i) a model parameterization based on simulated particle concentrations, (ii) the same parameterization based on gravimetrical particle measurements, (iii) direct $\mathrm{CCN}$ measurements with a $\mathrm{CCN}$ counter, and (iv) lidarderived and in situ measured vertical CCN profiles. In order to allow for sensitivity studies of the anthropogenic impact, a scenario to estimate the maximum $\mathrm{CCN}$ concentration under peak aerosol conditions of the mid-1980s in Europe was developed as well. In general, the simulations are in good agreement with the observations. At ground level, average values between 0.7 and $1.5 \times 10^{9} \mathrm{CCN} \mathrm{m}^{-3}$ at a supersaturation of $0.2 \%$ were found with the different methods under present-day conditions. The discrimination of the chemical species revealed an almost equal contribution of ammonium sulfate and ammonium nitrate to the total number of $\mathrm{CCN}$ for present-day conditions. This was not the case for the peak aerosol scenario, in which it was assumed that no ammonium nitrate was formed while large amounts of sulfate were present, consuming all available ammonia during ammonium sulfate formation. The $\mathrm{CCN}$ number concentration at five different supersaturation values has been compared to the mea-
\end{abstract}

surements. The discrepancies between model and in situ observations were lowest for the lowest $(0.1 \%)$ and highest supersaturations $(0.7 \%)$. For supersaturations between $0.3 \%$ and $0.5 \%$, the model overestimated the potentially activated particle fraction by around $30 \%$. By comparing the simulation with observed profiles, the vertical distribution of the $\mathrm{CCN}$ concentration was found to be overestimated by up to a factor of 2 in the boundary layer. The analysis of the modern (year 2013) and the peak aerosol scenario (expected to be representative of the mid-1980s over Europe) resulted in a scaling factor, which was defined as the quotient of the average vertical profile of the peak aerosol and present-day CCN concentration. This factor was found to be around 2 close to the ground, increasing to around 3.5 between 2 and $5 \mathrm{~km}$ and approaching 1 (i.e., no difference between present-day and peak aerosol conditions) with further increasing height.

\section{Introduction}

Compared to today, in the 1980s the anthropogenic emission of aerosols and precursor gases was much higher (Vestreng et al., 2007; Smith et al., 2011). Presumably, during this time the loads of such aerosols over this region were at their maximum. Since at least the 1990s anthropogenic emissions of aerosols and precursor gases in central Europe have been decreasing (e.g., Smith et al., 2011). 
Atmospheric aerosol particles play an important role in the microphysical processes of cloud formation (Köhler, 1936) and thus have a potentially large influence on cloud properties. However, the evaluation of their effects still shows large uncertainties (e.g., Boucher et al., 2013). In order to reduce those uncertainties, parameterizations to estimate the number concentrations of the cloud condensation nuclei $(\mathrm{CCN})$ have been developed for application in models. For a realistic simulation of microphysical aerosol-cloud interactions and macroscopic cloud adjustment due to aerosol perturbations, a detailed representation of the aerosol in the models is required. To describe the activation of aerosol particles, the chemical composition, the number concentration, and the size distribution of the aerosol particles have to be known. Parameterizations of the cloud droplet activation (e.g., Abdul-Razzak et al., 1998; Abdul-Razzak and Ghan, 2000; Petters and Kreidenweis, 2007) apply the Köhler theory (Köhler, 1936) and have been implemented into regional chemistry transport models (e.g., Bangert et al., 2011; Hande et al., 2016). The influence of the droplet activation on the aerosol composition is described using the aerosol hygroscopicity, e.g., represented by the hygroscopicity parameter kappa $(\kappa)$. These parameterizations enable the investigation of the interaction of the aerosol population with cloud microphysical properties.

For the regional chemistry transport model (CTM) that is used in this study (COSMO-MUSCAT, Wolke et al., 2012; see Sect. 2.1) Sudhakar et al. (2017) extended the model system to allow aerosol-cloud interactions by applying the twomoment cloud microphysics scheme by Seifert and Beheng (2006). This model version is interactively coupled online, making the activation of aerosol mass available for the twomoment scheme. However, the aerosol activation uses the bulk mass and does not explicitly consider online-computed aerosol microphysical properties. The complex consideration of aerosols and aerosol-cloud interactions in models, including the particle size distribution and composition, is expensive with regard to computation time and storage and thus not feasible, particularly for long-term applications.

Therefore, Hande et al. (2016) applied a combination of two existing models to produce a CCN climatology for use in limited-area models, representing normal background conditions over Europe. First, the aerosol particle mass concentrations were simulated using a CTM with a mass-based aerosol scheme. Following this, the CCN number concentration was calculated offline using the parametrization of Abdul-Razzak and Ghan (2000), utilizing assumed number size distributions and the modeled chemical composition of the aerosol.

Measurements of the $\mathrm{CCN}$ number concentration in the field are valuable in order to evaluate and constrain the ability of the models to describe the activation of aerosol particles. There are several recent studies of in situ observations (e.g., Henning et al., 2014; Hammer et al., 2014; Friedman et al., 2013). In situ CCN measurements were already performed in the 1950s and compared to the predicted CCN number (e.g.,
Twomey and Squires, 1959). The influence of the source region and the variation in concentration with height and region has also been investigated previously (e.g., Squires and Twomey, 1966; Hoppel et al., 1973). Furthermore, the derivation of vertical profiles of $\mathrm{CCN}$ with ground-based remote sensing methods was made possible (e.g., Ghan et al., 2006; Shinozuka et al., 2015; Mamouri and Ansmann, 2016; $\mathrm{Lv}$ et al., 2018) with the development of first approaches in the late 1990s (Feingold et al., 1998). Such datasets can be used to evaluate the application of available aerosol activation parameterizations in atmospheric models. Evaluated against in situ observations, the applied regional and global models (e.g., Spracklen et al., 2011; Bègue et al., 2015; Schmale et al., 2019; Fanourgakis et al., 2019; Watson-Parris et al., 2019) tend to underestimate the observed CCN concentrations.

The aim of this study is to provide estimates of the concentrations of cloud condensation nuclei (CCN) representative of the mid-1980s over Germany and compare those to simulations and observations in the year 2013. The derived time-varying 3D CCN fields were used as input for high-resolution simulations over Germany in the framework of the High Definition Clouds and Precipitation for advancing Climate Prediction ( $\mathrm{HD}(\mathrm{CP})^{2}$ ) project (see Heinze et al., 2017; Costa-Surós et al., 2020). A similar approach as that of Hande et al. (2016) was applied to derive CCN from modeled aerosol mass concentrations. The mass concentrations of the aerosol species were simulated using the regional CTM COSMO-MUSCAT with a mass-based aerosol scheme for two periods of the $\mathrm{HD}(\mathrm{CP})^{2}$ Observational Prototype Experiments (HOPE, Macke et al., 2017) in 2013. Based on the modeled aerosol mass concentrations and assumed particle number size distributions for each aerosol species, the CCN number concentrations were calculated offline using the activation parametrization by Abdul-Razzak and Ghan (2000). The parameterization calculates the number of activated aerosol particles for an aerosol population consisting of multiple lognormal aerosol size distributions and multiple aerosol types. The number of activated aerosol particles depends on the number size distributions of the aerosol population, its chemical composition, and the applied supersaturation (e.g., fixed or derived from updraft velocities). Thus, this approach is very versatile and can be applied for each type of aerosol mixture. The resulting modeled $\mathrm{CCN}$ fields can be used in atmospheric models that do not treat aerosol transport explicitly to analyze clouds and their radiation effects. For this purpose, $\mathrm{CCN}$ fields of a variable degree of complexity can be generated, e.g., temporally and spatially constant CCN profiles, a 3D CCN field as a long-term average, or even a 4D CCN field for temporally limited episodes. For the year 2013, the CCN number concentrations derived or measured with four different methods were compared: (i) $\mathrm{CCN}$ derived from COSMO-MUSCAT simulations of aerosol mass concentrations, (ii) $\mathrm{CCN}$ derived from gravimetrical aerosol mass measurements, (iii) ground-based in situ measurements 
of cloud condensation nucleus counter (CCNC), and (iv) vertical CCN profiles derived from ground-based lidar remote sensing and observed by helicopter-borne in situ measurements.

In order to estimate the $\mathrm{CCN}$ concentrations in the mid1980s over Europe, the aerosol concentrations from the 2013 simulation were scaled based on emission estimates for Germany of the year 1985 . The derived CCN fields for the mid1980s scenario were compared to the 2013 simulation and the observations of the year 2013.

This paper is structured as follows. First, the applied CTM COSMO-MUSCAT and the different observation techniques are introduced and necessary assumptions are described. In Sect. 3, the results of the comparison of $\mathrm{CCN}$ number concentrations obtained from the different methods are discussed. Conclusions and a summary can be found in Sect. 4 .

\section{Methods}

\subsection{Model description}

\section{COSMO-MUSCAT}

For this study, the chemistry transport model system COSMO-MUSCAT (Wolke et al., 2012) was used. It consists of the meteorological model COSMO (COnsortium for Small scale MOdelling), which is the operational forecast model of the German Weather Service (DWD), and the chemistry transport model MUSCAT (MUltiScale Chemistry Aerosol Transport). COSMO is driven by initial and boundary data from GME reanalysis (the global model of DWD operational in 2013; Majewski et al., 2002). After a spin-up phase for COSMO of $24 \mathrm{~h}$, both models run coupled online for $48 \mathrm{~h}$. To ensure that the meteorology stays close to the real meteorological conditions, the meteorological fields are then re-initialized for the next simulation cycle. The trace gas and aerosol fields are kept from the last time step of the previous cycle to ensure a continuous simulation. The online coupling has the advantage that the meteorological fields from COSMO are forwarded to MUSCAT in every time step. The meteorological fields drive the chemical transformation and atmospheric transport treated in MUSCAT for several gas-phase and aerosol species. Transport processes include advection, turbulent diffusion, sedimentation, and dry and wet deposition. MUSCAT is based on mass balances, which are described by a system of time-dependent, threedimensional advection-diffusion reaction equations. Emissions of anthropogenic primary particles and precursors of secondary aerosols are prescribed using emission fields from EMEP (European Monitoring and Evaluation Programme, EMEP, 2009). Emissions of natural primary aerosols (Saharan desert dust, primary marine aerosol particles) are computed within the model (e.g., Heinold et al., 2011), using meteorological fields (surface wind speed, precipitation) from the model itself in addition to information on surface properties.

\subsection{Model setup}

The study presented here is part of the High Definition Clouds and Precipitation for advancing Climate Prediction $\left(\mathrm{HD}(\mathrm{CP})^{2}\right)$ project. The main objective is to improve our understanding of clouds and precipitation using a model for very high resolution simulations. In the ICON-LEM (ICOsahedral Non-hydrostatic Large Eddy Model; Zängl et al., 2015; Dipankar et al., 2015; Heinze et al., 2017), which is the model used in $\mathrm{HD}(\mathrm{CP})^{2}$, there is no online aerosol transport scheme, which indicates the need for prescribing the aerosol and $\mathrm{CCN}$ concentrations in order to be considered for aerosol-cloud interaction.

In order to provide time-varying 3D fields of $\mathrm{CCN}$ concentrations for ICON-LEM, model simulations with COSMOMUSCAT covering most of Germany have been carried out for the time period of two intensive measurement campaigns during $\mathrm{HD}(\mathrm{CP})^{2}$ : HOPE. The resulting cloud properties in the ICON-LEM simulation using the derived CCN fields from this study are analyzed and discussed by Costa-Surós et al. (2020). The HOPE campaigns cover the time periods between 3 April and 31 May and 1 and 30 September 2013 (see Sect. 2.3). Data from the measurement site in Melpitz, Germany, were used for comparison during both campaigns. In addition, lidar-based $\mathrm{CCN}$ concentrations were available during the spring campaign in Jülich, Germany.

The model domain investigated in this study is displayed in Fig. 1 and covers the area between 48.25 and $54^{\circ} \mathrm{N}$ and 6 and $15^{\circ} \mathrm{E}$. The horizontal resolution was set to $7 \mathrm{~km}$. In the vertical, the model treats 50 layers up to a height of $22 \mathrm{~km}$. As lateral boundary conditions for the trace gases and aerosol species, modeled fields of atmospheric chemical composition originating from a coarser simulation on a European domain are utilized. This coarser surrounding simulation is driven by reanalysis data for meteorology (reanalysis product of DWD using the GME model) and atmospheric chemical composition (CAMS (Copernicus Atmosphere Monitoring Service) reanalysis product; Inness et al., 2019). The temporal resolution for the model output was set to $1 \mathrm{~h}$. In addition to the standard meteorological model output from COSMO, MUSCAT provides the mass concentrations of several gas-phase and aerosol species.

\subsubsection{Aerosol particle number estimation and CCN parametrization}

Using the aerosol bulk scheme of COSMO-MUSCAT, the mass concentrations for the species considered are simulated. In order to compare the model results with in situ particle measurements and to calculate number concentrations of $\mathrm{CCN}$, particle number size distributions (PNSDs) have to be estimated from those mass concentrations. For each species 


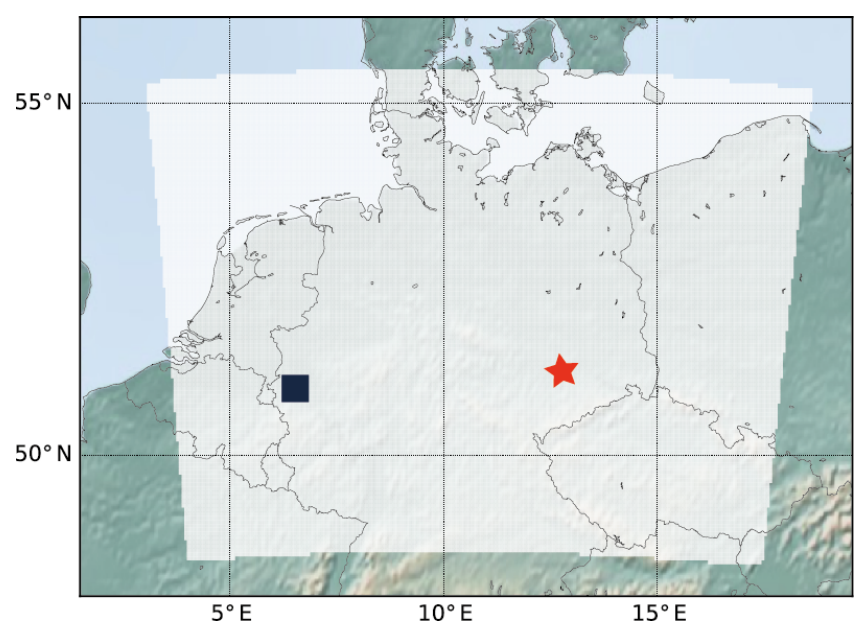

Figure 1. Model domain over Germany that was used in this study (white area). The red star marks the research station Melpitz $\left(51.53^{\circ} \mathrm{N}, 12.93^{\circ} \mathrm{E}\right)$, and the black square marks the measurement site Jülich $\left(50.88^{\circ} \mathrm{N}, 6.41^{\circ} \mathrm{E}\right)$.

of the anthropogenic aerosol, i.e., ammonium sulfate (AS), ammonium nitrate (AN), sulfate (SU), organic (OC), and elemental carbon (EC), as well as for sea salt (SS) as part of the natural aerosol, individual lognormal size distributions are assumed. The size distribution of the mineral dust (DU) particles follows a sectional scheme (Heinold et al., 2011). A lognormal size distribution is explicitly defined with the three parameters of diameter or radius ( $d$ or $r$, respectively), standard deviation $(\sigma)$, and total number concentration $(N)$. For the externally mixed aerosols, the total number concentration of each species is calculated from the modeled mass of the aerosol species assuming an individual geometric mean radius and standard deviation. The choice of these parameters defines the aerosol number size distribution and is a critical source for uncertainty of aerosol and CCN number concentrations. Within the $\mathrm{HD}(\mathrm{CP})^{2}$ framework, literature values, aerosol mass spectrometer (AMS) measurements, and particle number size distribution measurements in the diameter range $10 \mathrm{~nm}$ to $10 \mu \mathrm{m}$ from the TROPOS site Melpitz, Germany (Poulain et al., 2011), which is representative of central Europe (e.g., Spindler et al., 2012; Engler et al., 2007), were used to define the parameters for the lognormal distributions. Adding up the different size distributions of all considered species gives the total particle number size distributions. The calculations have been compared to observational data and showed a good agreement with the observed total size distribution at Melpitz between 50 and $200 \mathrm{~nm}$ (Hande et al., 2016), which is a very relevant size range for estimating $\mathrm{CCN}$ in the supersaturation range investigated in this study $(0.1 \%-$ $0.7 \%$ ). The geometric mean radius, standard deviation, and density for characterizing the particle number size distributions of the individual aerosol species are listed in Table 1, mostly according to the values used in Hande et al. (2016).
The number size distributions of the aerosol species was then used to calculate the number of activated particles under certain conditions. The calculation of the CCN number concentration in this study follows the parameterization of Abdul-Razzak and Ghan (2000) for multimodal aerosol distributions, which relates the particle number size distribution and composition to the number of activated particles as a function of supersaturation. The individual aerosols compete for the available liquid water, determining the maximum supersaturation, which apart from the aerosol composition and individual size distributions also depends on the updraft velocity. Abdul-Razzak et al. (1998) describe the parameterization for a single lognormal mode of aerosol particles (only for a single species), whereas Abdul-Razzak and Ghan (2000) developed an extended approach for multiple soluble and insoluble aerosol species, representing a multimodal aerosol size distribution. The parameterization uses the hygroscopicity parameter $\kappa$ of each considered aerosol species. The $\kappa$ values used in this study can be found in Table 1 as well. $\kappa$ was defined first in Petters and Kreidenweis (2007) as a single parameter to describe the relationship between the particle dry diameter, its hygroscopicity, and the CCN activation. In several laboratory studies, $\kappa$ has been determined experimentally. Highly hygroscopic particles can have a $\kappa>1$, while for totally hydrophobic particles $\kappa=0$. Petters and Kreidenweis (2007) reported $\kappa$ for a number of different compounds, e.g., ammonium sulfate being about 0.6 in the supersaturation regime. Further studies investigated $\kappa$ for other substances, like sea salt (e.g., Niedermeier et al., 2008), coated soot (e.g., Henning et al., 2010), and secondary organic aerosol (e.g., Wex et al., 2009; Duplissy et al., 2011), or depending on the mixing state of the particles (Wex et al., 2010).

The same size distributions as those applied in this study to derive $\mathrm{CCN}$ concentrations from the modeled aerosol mass were utilized in a related study of the $\mathrm{HD}(\mathrm{CP})^{2}$ project by Hande et al. (2016). They evaluated the aerosol size distribution at Melpitz and found good agreement in the size range between 50 and $200 \mathrm{~nm}$. We therefore assume that the applied method generally produces realistic CCN concentrations, as the critical size of activation usually falls within this range for the supersaturations applied in this study and aerosol particles in this range are usually more numerous than larger particles. However, the ambient aerosol size distribution varies in time and space, and therefore the assumption of a spatially and temporally constant size distribution for the different aerosol species is a source of uncertainty. For the example of $1 \mu \mathrm{g} \mathrm{m}^{-3}$ ammonium sulfate aerosol, using the assumptions given in Table 1, the number of activated aerosols is $215 \mathrm{~cm}^{-3}$ at supersaturation of $0.2 \%$. By varying the geometric mean radius of the assumed size distribution by $\pm 10 \%$ but keeping the total mass constant, the CCN concentration varies by $\pm \sim 15 \%$. Widening the distribution using $\sigma=1.7$ instead of 1.6 leads to a decrease of $\sim 25 \%$ in $\mathrm{CCN}$ number concentration at $0.2 \%$ supersaturation since 
Table 1. Physical and chemical aerosol properties used in this study. The values for the particle radius and standard deviation of the size distribution follow Poulain et al. (2011), Spindler et al. (2012) (nondust species), and Heinold et al. (2011) (mineral dust). Several laboratory and model studies served as the basis for the $\kappa$ values used in this study (ammonium sulfate: Ghan et al., 2001, Petters and Kreidenweis, 2007; ammonium nitrate: Duplissy et al., 2011; sulfate: Petters and Kreidenweis, 2007; OC: Ghan et al., 2001, Wex et al., 2009; sea salt, dust, and EC: Ghan et al., 2001).

\begin{tabular}{lrcrr}
\hline Species & $\kappa$ & $\sigma$ & $r(\mu \mathrm{m})$ & $\rho\left(\mathrm{kg} \mathrm{m}^{-3}\right)$ \\
\hline Ammonium sulfate & 0.51 & 1.6 & 0.05 & 1.77 \\
Ammonium nitrate & 0.54 & 1.6 & 0.05 & 1.725 \\
Sulfate & 1 & 1.6 & 0.05 & 1.8 \\
Sea salt 1 & 1.16 & 1.8 & 0.065 & 2.2 \\
Sea salt 2 & 1.16 & 1.7 & 0.645 & 2.2 \\
EC & $5 \times 10^{-7}$ & 1.8 & 0.03 & 1.8 \\
OC & 0.14 & 1.8 & 0.055 & 1.0 \\
Mineral dust 1 & 0.14 & 2.0 & 0.2 & 2.65 \\
Mineral dust 2 & 0.14 & 2.0 & 0.6 & 2.65 \\
Mineral dust 3 & 0.14 & 2.0 & 1.75 & 2.65 \\
Mineral dust 4 & 0.14 & 2.0 & 5.25 & 2.65 \\
Mineral dust 5 & 0.14 & 2.0 & 15.95 & 2.65 \\
\hline
\end{tabular}

the total particle number decreases due to more large particles that are large in volume.

In order to evaluate these assumptions, the modeled $\mathrm{CCN}$ number concentrations were compared to measurements close to the ground for the TROPOS super-site Melpitz. For this purpose, the same supersaturations as those applied in the CCNC (Henning et al., 2014) were applied to the simulated particle number size distributions (see Sect. 2.3.1).

\subsubsection{Estimation of peak aerosol in the mid-1980s}

In order to allow for sensitivity studies on the impact of anthropogenic pollution on $\mathrm{CCN}$ concentrations, a scenario to estimate aerosol concentrations over central Europe in the mid-1980s was developed. Due to the maximum emissions of aerosols and precursor gases in Europe during the 1980s, the year 1985 was taken as a reference year for the emissions. In the early 1990s, environmental protection became much more important and efficient emission reduction strategies were developed. Furthermore, many aerosol and precursor sources simply disappeared after the liquidation of several industrial sites in the former East Germany and the former Eastern Bloc countries after the political changes of 1990.

The calculations for the mid-1980s were carried out offline with the model run from 2013 as a basis. The annual emissions of sulfur dioxide and ammonia during the years 1985 and 2013 (see Table 2) were utilized for these estimations (Umweltbundesamt, UBA, German Federal Environmental Agency; Kevin Hausmann, personal communication, 2017). The scaling factors derived in order to estimate the aerosol concentrations for the mid-1980s scenario based on
Table 2. Annual emissions of dust, sulfur dioxide, and ammonia for all of Germany for the years 1985 and 2013 in megatonnes, as provided by Umweltbundesamt (German Federal Environmental Agency, UBA, Kevin Hausmann, personal communication, 2017). So-called dust also includes, e.g., soot and resuspended material, aside from the natural mineral dust. The table also includes the factors by which the concentrations in 2013 are scaled in order to estimate the concentrations for the mid-1980s scenario.

\begin{tabular}{lrrr}
\hline & 1985 & 2013 & ratio $1985 / 2013$ \\
\hline Dust (incl. soot) & 2.65 & 0.35 & 7.7 \\
$\mathrm{SO}_{2}$ & 7.73 & 0.41 & 19 \\
$\mathrm{NH}_{3}$ & 0.86 & 0.74 & 1.2 \\
\hline
\end{tabular}

the present-day simulation are summarized in Table 3. The model implementation of the formation of ammonium sulfate $\left(\left(\mathrm{NH}_{4}\right)_{2} \mathrm{SO}_{4}\right)$ and ammonium nitrate $\left(\mathrm{NH}_{4} \mathrm{NO}_{3}\right)$ is described by Hinneburg et al. (2009) and follows Simpson et al. (2003). Particulate ammonium sulfate can be formed in the atmosphere from sulfuric acid (formed after oxidation of $\mathrm{SO}_{2}$ ) and ammonia. In the model, first ammonium sulfate is formed until either ammonia or sulfuric acid is consumed. In cases where there is still ammonia left after this reaction, ammonium nitrate can be formed as well. As can be seen from Table 2, almost 20 times more $\mathrm{SO}_{2}$ was emitted in Germany during the 1980s compared to 2013, whereas $\mathrm{NH}_{3}$ emissions remained almost unchanged. For this reason, there was much more sulfuric acid available in the atmosphere than necessary for the transformation of the total available ammonia to ammonium sulfate. In 2013, $\mathrm{SO}_{2}$ and $\mathrm{NH}_{3}$ react to ammonium sulfate until $\mathrm{SO}_{2}$ is consumed, leading to the formation of $0.85 \mathrm{Mt}$ ammonium sulfate. For the mid-1980s conditions, in the implemented scheme, first $\mathrm{NH}_{3}$ is consumed, and in total $3.32 \mathrm{Mt}$ ammonium sulfate is formed. This results in a scaling factor for ammonium sulfate of 3.9. In this $\mathrm{SO}_{2}$ limited regime in 2013, there would not be any $\mathrm{NH}_{3}$ left to produce ammonium nitrate. The inhomogeneous distribution and the time-dependent formation would still enable nitrate formation in reality. However, since assumed density, size distribution, and hygroscopicity of ammonium sulfate and ammonium nitrate are similar, exchanging part of the ammonium sulfate with ammonium nitrate and vice versa would not introduce strong changes to the calculated $\mathrm{CCN}$ number concentration, which is the aim of this study. This is why the production of ammonium nitrate was set to zero for the mid-1980s scenario. The ammonium sulfate formation leaves $6.1 \mathrm{Mt} \mathrm{SO}_{2}$ unconsumed. Half of this excess $\mathrm{SO}_{2}$ left after ammonium sulfate formation in the mid-1980s is assumed to be oxidized to sulfuric acid. Sulfuric acid is assumed to entirely partition to the particulate phase and is therefore accounted for as sulfate. The approach described above is also encouraged by the serious acid rain problem in the 1980s (e.g., Seinfeld and Pandis, 1998, p. 1030ff). Since no excess sulfate is present in the 2013 simulation, we calculate 
Table 3. Assumptions for the estimation of the aerosol conditions for the mid-1980s over Germany.

\begin{tabular}{lll}
\hline & 2013 & mid-1980s scenario \\
\hline Ammonium sulfate & $\mathrm{AS}_{2013}$ & $\mathrm{AS}_{2013} \cdot 3.9$ \\
Ammonium nitrate & $\mathrm{AN}_{2013}$ & 0 \\
Sulfate & $\mathrm{SU}_{2013}$ & $\mathrm{AS}_{2013} \cdot 5.3$ \\
EC & $\mathrm{EC}_{2013}$ & $\mathrm{EC}_{2013} \cdot 2$ \\
OC & $\mathrm{OC}_{2013}$ & $\mathrm{OC}_{2013}$ \\
Sea salt & $\mathrm{SS}_{2013}$ & $\mathrm{SS}_{2013}$ \\
Mineral dust & $\mathrm{DU}_{2013}$ & $\mathrm{DU}_{2013}$ \\
\hline
\end{tabular}

the sulfate concentration for the mid-1980s scenario based on the 2013 ammonium sulfate concentration. The ratio between the formed sulfate in the mid-1980s scenario $(4.68 \mathrm{Mt})$ and the formed ammonium sulfate in $2013(0.85 \mathrm{Mt})$ results in a scaling factor of 5.3. Since no emission data for elemental carbon for the 1980s were available, the particle concentrations were assumed to be twice as high as in 2013. This is only justified by the fact that aerosol concentrations in the 1980s over central Europe were higher than today, which was mainly caused by combustion processes for heating and energy production. Organic carbon, sea salt, and dust are supposed to result mostly from natural sources and thus remain unchanged for the mid-1980s scenario.

Due to lack of observational data of aerosol size distributions in the 1980s in the study region to generalize size distributions during this time, for this study the same size distributions for the mid-1980s scenario and 2013 were assumed. Since the size distribution is crucial in order to translate modeled aerosol mass into particle numbers and finally derive $\mathrm{CCN}$ numbers, this assumption is likely an important source of uncertainty, which is difficult to quantify reliably.

The above scaling approach, instead of conducting actual simulations for the 1980s, implies that any observed differences between mid-1980s and 2013 aerosol and CCN concentrations are due to changes in the emissions only and are not caused by differences in meteorological conditions. However, the results have to be interpreted carefully and can only represent a rough general estimate of the mid-1980s conditions and hence are not representative of the specific conditions of a particular year or period of the 1980s. The results of the comparison of the number concentrations in 2013 and the mid-1980s are presented in Sect. 3.

\subsection{Measurements during HOPE}

The present study utilizes observational data from the extensive measurements conducted during the two HOPE campaigns (3 April to 31 May and 1-30 September 2013) at the TROPOS research station Melpitz and the measurement site near Jülich, Germany. At Melpitz, additional long-term measurements of in situ aerosol PNSD, CCN concentrations, and chemical composition of the aerosol particles are avail- able. The rural background site Melpitz $\left(51.53^{\circ} \mathrm{N}, 12.93^{\circ} \mathrm{E}\right.$; $86 \mathrm{~m}$ a.s.l.) is located in Germany, $\sim 40 \mathrm{~km}$ east of Leipzig in the eastern German lowlands. The site, which is in a meadow, is surrounded by agricultural land. It is representative of a large area in central Europe, and long-term studies with consideration of marine or continental air mass inflow enable the investigation of the influence of different spatially distributed emission sources and long-range transport on particulate matter (PM) concentrations (Engler et al., 2007; Spindler et al., 2013). The Melpitz site is integrated in the infrastructure network ACTRIS (Aerosols, Clouds, and Trace gases Research Infrastructure Network, http://www.actris.eu, last access: 16 July 2020) and EMEP (Co-operative Programme for Monitoring and Evaluation of the Long-Range Transmission of Air Pollutants in Europe; Tørseth et al., 2012). From the spring campaign at Jülich, only the lidar measurements were used to derive vertical profiles of $\mathrm{CCN}$ concentrations.

The idea behind the HOPE campaigns was to gain a comprehensive dataset of observations for evaluation of the new German operational forecast model ICON at the scale of a couple hundred meters (ICON-LEM). The campaign focused on the convective atmospheric boundary layer, especially the connection of clouds and precipitation. Technically, HOPE aimed to combine most of the surface flux and mobile ground-based remote-sensing observations available in Germany within a single domain for the purpose of describing the vertical structure and horizontal variability of wind, temperature, humidity, aerosol particles, and cloud droplets in a high temporal and spatial resolution.

Additionally, during the fall campaign, in situ observations with the helicopter-borne platform ACTOS (Airborne Cloud Turbulence Observation System, Siebert et al., 2006) were combined with aerosol and cloud properties observed with remote sensing at the LACROS (Leipzig Aerosol and Cloud Remote Observations System, Bühl et al., 2013) supersite. This dataset allows for the investigation of the relationship between tropospheric clouds and aerosol conditions.

Detailed information on the meteorological conditions during the two campaigns can be found in Macke et al. (2017), their Tables 3 and 4. The weather situations during the spring campaign changed from a few high-pressure systems with high-level cirrus clouds, interrupted by several frontal passages (warm and cold fronts) at the beginning of the campaign, followed by more shallow convective clouds later on. The fall period was dominated by low-level overcast clouds.

\subsubsection{In situ CCNC measurements - ground-based and airborne}

Ground-based in situ measurements with the CCNC have been operational in Melpitz since August 2012 (Schmale et al., 2017), and the results were available for model evaluations within this study. The ambient CCN number concentration at Melpitz station was determined by means of 
size-segregated activation measurements as described in detail in Henning et al. (2014), following the ACTRIS SOP (standard operating procedures; Gysel and Stratmann, 2013). Briefly, the setup is as follows, downstream of the aerosol inlet and the drier unit, an aerosol flow of $1.5 \mathrm{~L} \mathrm{~min}^{-1}$ is size-selected with a DMPS (differential mobility particle sizing) system and afterwards divided between a condensation particle counter $\left(1 \mathrm{~L} \mathrm{~min}^{-1}\right.$ working flow; CPC 3010 , TSI Aachen, Germany) and a CCNC $\left(0.5 \mathrm{~L} \mathrm{~min}^{-1}\right.$ working flow; CCN-100, Boulder, USA). With the CCNC, a streamwise thermal gradient cloud condensation nucleus counter (Roberts and Nenes, 2005), the supersaturation-dependent activation of the particles is investigated at $0.1 \%, 0.2 \%$, $0.3 \%, 0.5 \%, 0.7 \%$, and $1 \%$ supersaturation. The ratio between the $\mathrm{CCN}$ number and the total particle number as counted by the CPC (condensation nuclei, $\mathrm{CN}$ ) gives the activated fraction (AF) of the particles. The AF was corrected for multiply charged particles up to three charges by subtracting their apparent fraction from the $\mathrm{AF}$ using the charge equilibrium (Wiedensohler, 1988). This multiple charge-corrected $\mathrm{AF}$ is calculated for each particle diameter and results in a size-dependent activation curve for each supersaturation. This curve is fitted with a sigmoidal function describing the activation curve with the following four parameters: lower activation limit, upper limit, sigma $(\sigma)$, and critical diameter $\left(D_{\mathrm{c}}\right)$. Multiplying the activation curve $(\mathrm{CCN} / \mathrm{CN})$ with the ambient size distribution integral results in the ambient $\mathrm{CCN}$ number concentration at the given supersaturation. One measurement per supersaturation is available every $2 \mathrm{~h}$.

During the fall measurement campaign of HOPE the helicopter-borne measurement platform ACTOS was deployed in Melpitz in addition to the permanent instruments. The experimental setup and the flight characteristics are described in detail by Düsing et al. (2018). Within this study we use the vertically resolved in situ data of the lightweight mini cloud condensation nuclei counter (mini-CCNC, custom built by Gregory C. Roberts, working principally as described by Roberts and Nenes, 2005), which has been applied successfully on ACTOS before (e.g., Wex et al., 2016). The mini-CCNC measured the CCN number concentration at a supersaturation of $0.2 \%$. Vertical profile measurements are available for eight flights between 12 and 27 September 2013.

\subsubsection{Daily $\mathbf{P M}_{10}$ sampling at Melpitz site}

Particles with aerodynamic diameter up to $10 \mu \mathrm{m}\left(\mathrm{PM}_{10}\right)$ were sampled daily at the Melpitz site. PM high-volume quartz filter samples for $\mathrm{PM}_{10}$ were collected using a high-volume sampler (DIGITEL DHA-80, Walter Riemer Messtechnik, Germany) that had a sampling flux of about $30 \mathrm{~m}^{3} \mathrm{~h}^{-1}$. The filter type is a MK 360 quartz fiber filter (Munktell, Grycksbo, Sweden). The measurement techniques to determine the particle mass, water soluble ions, and carbonaceous particles are described by Spindler et al. (2013,
2012). The particle mass determination was performed gravimetrically. The conditioned filters $\left(72 \mathrm{~h}\right.$ at $20^{\circ} \mathrm{C}$ and $50 \%$ relative humidity) were weighted with a microbalance as tare weight (blank) and after sampling of particles as gross weight. The main water-soluble ions $\left(\mathrm{NO}^{3-}, \mathrm{SO}_{4}^{2-}, \mathrm{Cl}^{-}\right.$, $\mathrm{Na}^{+}, \mathrm{NH}^{4+}, \mathrm{K}^{+}, \mathrm{Mg}^{2+}, \mathrm{Ca}^{2+}$ ) were analyzed by ion chromatography. The determination of organic and elemental carbon (OC and EC) was performed by a two-step thermographic method using a carbon analyzer (behr LaborTechnik, Germany). OC was vaporized at $650^{\circ} \mathrm{C}$ for $8 \mathrm{~min}$ under a nitrogen atmosphere and catalytically converted to $\mathrm{CO}_{2}$, and the remaining $\mathrm{EC}$ was combusted further in $8 \mathrm{~min}$ with $\mathrm{O}_{2}$ at $650^{\circ} \mathrm{C}$. The formed $\mathrm{CO}_{2}$ was than quantitatively determined by a nondispersive infrared detector (modified German standard Verein Deutscher Ingenieure (VDI) method 2465 part 2).

\subsubsection{CCN concentrations derived by lidar measurements}

During the HOPE campaigns, PollyXT lidar systems (Engelmann et al., 2016) were used to measure the vertical state of the atmosphere automatically and continuously in terms of aerosol particles and clouds. Lidar observations were performed in Melpitz (fall campaign) and Jülich (spring campaign) with the 12-channel multiwavelength polarization lidar PollyXT_OCEANET. Hourly averaged profiles of the particle backscatter and extinction coefficient, as well as the particle depolarization ratio, were calculated automatically for the whole measurement period as described in Baars et al. (2016). As the particle depolarization ratio was close to zero (indicator for spherical particles) for the whole period, one can conclude that no dust intrusion was occurring during the intensive field campaigns. Thus, the $\mathrm{CCN}$ concentration profiles were calculated following the continental aerosol branch in Mamouri and Ansmann (2016).

For this approach, the lidar-derived particle backscatter profiles are converted to extinction profiles by using a lidar ratio of $50 \mathrm{sr}$ as a typical value for continental (subscript c) sites (Baars et al., 2017). The aerosol number concentration profiles for particles with a dry radius $>50 \mathrm{~nm}\left(n_{50}\right)$ are calculated using

$n_{50, \mathrm{c}, \mathrm{dry}}(z)=c_{60, \mathrm{c}} \sigma_{\mathrm{c}}^{X_{\mathrm{c}}}(z)$,

with $c_{60, \mathrm{c}}=25.3 \mathrm{~cm}^{-3}$ and $X_{\mathrm{c}}=0.94$ (see Mamouri and Ansmann, 2016 for details). Finally, the CCN concentration at supersaturations $<0.2 \%$ is estimated by multiplying $n_{50}$ with an enhancement factor of $f=1$. The uncertainty of this estimation is at a factor of 2-3 according to Mamouri and Ansmann (2016). 


\section{Results}

\subsection{Aerosol optical thickness}

The simulations described in this work were also evaluated by Costa-Surós et al. (2020). They present a comparison of aerosol optical thickness (AOT) over the North Sea and Baltic Sea as observed by the AVHRR (Advanced Very High Resolution Radiometer) instrument onboard different NOAA satellites and modeled by COSMO-MUSCAT. The observational platform represents a good opportunity to evaluate the modeled aerosol load for both 2013 and the 1980s conditions since the dataset dates back to 1981 . The modeled and observed AOT were shown to agree well for both the 2013 period and the mid-1980s conditions (using the observational example of the year 1985). The observed median AOT values over the Baltic sea for 1985 and 2013 were 0.30 and 0.14, respectively, and over the North Sea the values were 0.25 and 0.14 . The modeled values were 0.30 and 0.11 for the Baltic Sea and 0.22 and 0.09 for the North Sea. It can therefore be concluded that the model, using the assumptions discussed in this work, is able to represent the average aerosol loads of 2013 and the mid-1980s.

\subsection{Composition of $\mathrm{CCN}$}

As described above, number concentrations of $\mathrm{CCN}$ over Germany for two time periods of the year 2013 have been calculated offline from aerosol particle number concentrations based on simulated mass concentrations of seven different compounds: ammonium sulfate, ammonium nitrate, sulfate, organic and elemental carbon, sea salt, and mineral dust. Similarly, representing a peak aerosol scenario over Europe, aerosol concentrations have been calculated as representative of the mid-1980s based on the simulations for the year 2013 (see Sect. 2.2.2). Furthermore, the CCN parameterization has been applied to observed particle mass concentrations. The modeled CCN number concentrations were compared to ground-based in situ measurements by a CCNC and to vertical profiles derived from lidar and helicopter-borne in situ observations. Table 4 lists the total number concentration of $\mathrm{CCN}$ and the contribution of the individual compounds as average values for the simulated time period. Nowadays, the contributions of ammonium nitrate and ammonium sulfate are almost balanced. Due to the assumption that ammonium nitrate was not formed in the mid-1980s scenario, there is no contribution from ammonium nitrate to $\mathrm{CCN}$ in this time period. The concentration of ammonium sulfate in the atmosphere was far higher than today (see also Sect. 2.2.2), resulting in almost no ammonia being available for the formation of ammonium nitrate. Instead, much more sulfuric acid could form during this time period.

Comparing the two different methods of estimating today's CCN concentrations, differences can especially be seen for ammonium sulfate, organic carbon and mineral dust. The dust concentrations resulting from the gravimetrical methods are usually higher than simulated because they result from the difference of the total gravimetric mass and the sum of the masses of the individual species and are not directly measured. This is why the error is quite large due to losses of the other species during the analytical processes. Furthermore, they may contain undetected material other than only mineral dust and re-emitted soil dust, which is not included in the emission data used in the model simulations. The difference in $\mathrm{CCN}$ from OC is partly due to the absence of secondary organic aerosol (SOA) in the model approach. SOA generally can contribute a large fraction to the total concentration of organic aerosol mass with an average contribution over Europe ranging from $\sim 20$ to more than $50 \%$ (Jimenez et al., 2009). At Melpitz in summer, organic matter is also the major fraction (59\%) of the $\mathrm{PM}_{1}$ aerosol and is strongly influenced by SOA (Poulain et al., 2011).

Figure 2 shows the time series of derived $\mathrm{CCN}$ from the model simulation (Fig. 2a and b) and from gravimetrical aerosol measurements (Fig. $2 \mathrm{c}$ and d) for both the spring and fall period in comparison to the CCNC measurements at a supersaturation of $0.2 \%$. The same plot for a supersaturation of $0.3 \%$ is shown in Fig. A1 in the Appendix. On average (see Table 4), CCN concentrations derived from modeled and observed aerosol mass deviate from the $\mathrm{CCNC}$ measurements by a factor of around 1.2 (16\% underestimation) and 1.4 (37\% overestimation), respectively. Taking into account the uncertainty due to assumptions in converting observed or modeled aerosol mass into number, it is concluded that the used CCN parameterization works reasonably well on average. However, as can be seen in Fig. 2a and b, the performance of the model differs between the two time periods with the tendency to underestimate $\mathrm{CCN}$ concentrations in the spring period and overestimate it in the fall period (see also Fig. 3). In order to evaluate the applied method of deriving CCN concentrations from aerosol mass and its assumptions, the size distributions and the activation parameterization are applied to gravimetrical measurements of aerosol mass (Fig. 2c and d). The CCN concentrations derived from the gravimetrical measurements catch the peaks better in the first half of the spring episode and do not show the strong underestimation and overestimation, respectively, for the two periods as seen for CCN derived from the modeled aerosol mass. Since the activation parameterization is applied to both the modeled and observed aerosol mass, differences in the derived $\mathrm{CCN}$ concentrations between the upper and the lower panels of Fig. 2 correspond directly to uncertainties in the actual aerosol simulation with the atmospheric transport model. Particularly in the first half of the spring episode, ammonium nitrate and ammonium sulfate concentrations, and thus their contributions to the $\mathrm{CCN}$ number concentration, were clearly underestimated (see also Hande et al., 2016, Fig. 2). However, during the fall period the model often overestimates the concentration of ammonium sulfate and ammonium nitrate and hence the $\mathrm{CCN}$ concentrations. In particular, ammonium 
Table 4. Average $\mathrm{CCN}$ number concentration $\left(\mathrm{m}^{-3}\right)$ and average contribution $(\%)$ of the considered species to the total $\mathrm{CCN}$ number concentration at ground level for a supersaturation of $0.2 \%$ at the HOPE site Melpitz for the two 2013 campaigns and the corresponding periods of the mid-1980s scenario. The values were calculated from aerosol mass concentrations modeled with COSMO-MUSCAT and from aerosol mass concentrations observed by gravimetrical measurements. In addition, the average CCN number concentration measured in situ is shown for comparison.

\begin{tabular}{|c|c|c|c|c|c|c|c|c|}
\hline Database or scenario & $\mathrm{N}_{-} \mathrm{CCN}_{0.2 \%}, \mathrm{~m}^{-3}$ & AS & AN & SU & $\mathrm{EC}$ & $\mathrm{OC}$ & SS & DU \\
\hline Modeled aerosol mass concentrations (mid-1980s) & $5.2 \times 10^{9}$ & 36 & 0 & 64 & 0 & 0.4 & 0.3 & 0.001 \\
\hline Modeled aerosol mass concentrations (2013) & $9.4 \times 10^{8}$ & 51 & 46 & 0.007 & 0 & 2.3 & 1.6 & 0.008 \\
\hline Measured aerosol mass concentrations (2013) & $1.5 \times 10^{9}$ & 35 & 53 & 0 & 0 & 7.4 & 0.3 & 4.0 \\
\hline Direct observation of CCN with CCNC (2013) & $1.1 \times 10^{9}$ & & & & & & & \\
\hline
\end{tabular}

nitrate is sometimes strongly overestimated by up to a factor of 5. Deviations in ammonium nitrate might arise due to uncertainties in both modeling and observations. The emission of ammonia depends on agricultural activity (e.g., manuring). Hence, the magnitude and timing of observed ammonium nitrate concentration peaks cannot be represented by the model, which uses monthly emission estimates. Since nitrate is volatile, a high temperature within the sampling unit can lead to partial evaporation from the filters.

An interesting episode occurred between day-of-year (doy) 255 and 257 (12-14 September 2013) in the fall period, resulting in clearly overestimated $\mathrm{CCN}$ number concentrations in the model. This was caused by a small-scale low-pressure system, which moved southeastward over the measurement station at doy 255 and then continued eastward. The location of this low-pressure system was not correctly simulated, and the corresponding precipitation in northwestern Germany and the Netherlands on doy 254 and 255 was underestimated. This region represents one of the main ammonia sources and hence is important for the formation of ammonium nitrate and sulfate in the atmosphere. Due to the lack of precipitation in this region, wet deposition of aerosol particles and precursors was missing, resulting in an overestimation of aerosol mass concentration and hence CCN number concentration. The air mass rich in particularly ammonium nitrate traveled during doy 255-257 towards the measurement site at Melpitz. The underestimated wet deposition represents a likely cause for the overestimation seen during the $3 \mathrm{~d}$. However, other potential causes, such as incorrect emission or overestimated formation, cannot be ruled out. Since the gravimetrical observations also show a strong peak during these $3 \mathrm{~d}$, it can be concluded that the overall situation (emission, formation, transport) is still modeled reasonably.

\subsection{Comparison to in situ $\mathrm{CCN}$ measurements}

For a more evident comparison of the absolute $\mathrm{CCN}$ number concentrations, Fig. 3 displays the derived and measured CCN number concentrations at a supersaturation of $0.2 \%$ as a scatterplot for both episodes. As already seen in the time series plots in Fig. 2, the model tends to underestimate the
$\mathrm{CCN}$ numbers of the in situ $\mathrm{CCN}$ measurements in the spring episode (on average by $29 \%$ ). For the fall episode, an overestimation of $37 \%$ was found $(20 \%$ without the outliers of the $3 \mathrm{~d}$ discussed above). In contrast, the $\mathrm{CCN}$ number concentration estimated from the gravimetrically measured aerosol masses tends to overestimate the direct measurements in both periods (50\% in spring, $15 \%$ in fall). Together, Figs. 2, 3, and A1 show that the model underestimates the observed $\mathrm{CCN}$ concentration at least partly due to an underestimation of aerosol mass (mainly ammonium nitrate and ammonium sulfate) in the spring episode and overestimates the CCN concentration because of an overestimation of these aerosol species in the fall episode.

In Fig. 4 the ratio of the number concentrations of $\mathrm{CCN}$ (N_CCN) and the total aerosol particles (N_CN) larger than a certain size is shown as a comparison between simulation and observation. Figure $4 \mathrm{a}$ and $\mathrm{b}$ display the fractions for a supersaturation of $0.2 \%$ and particles larger than $110 \mathrm{~nm}$ for both episodes, and Fig. 4c and d show the same for a supersaturation of $0.3 \%$ and particles larger than $80 \mathrm{~nm}$, respectively. A ratio of exactly 1.0 means that as many particles would activate at the respective supersaturation, as aerosol particles with a diameter larger than the threshold diameter of $110 \mathrm{~nm}\left(\mathrm{~N}_{-} \mathrm{CN}_{110 \mathrm{~nm}}\right)$ and $80 \mathrm{~nm}\left(\mathrm{~N}_{-} \mathrm{CN}_{80 \mathrm{~nm}}\right)$, respectively, are present in the atmosphere at this time. For the rural observation site Melpitz, this ratio is usually close to 1.0 for $0.2 \%$ and $110 \mathrm{~nm}$, as well as for $0.3 \%$ and $80 \mathrm{~nm}$ (Silvia Henning, personal communication, 2017), which is why these two size threshold values were chosen. The N_CCN $0.2 \%$ to $\mathrm{N} \_\mathrm{CN}_{110 \mathrm{~nm}}$ ratios compare very well (on average 1.03 for the observations and 0.98 for the model), but the model tends to overestimate the N_CCN $0.3 \%$ to $\mathrm{N}_{-} \mathrm{CN}_{80 \mathrm{~nm}}$ ratios for both episodes (on average, 0.93 for the observations and 1.26 for the model). This can be the result of the model either overestimating the $\mathrm{CCN}$ concentration or underestimating the aerosol particle number in the size range larger than $80 \mathrm{~nm}$ in diameter. For both $0.2 \%$ and $0.3 \%$ supersaturation, the model underestimates the $\mathrm{CCN}$ concentration in total for both periods by a similar magnitude of $13 \%$ and $11 \%$, respectively (see also Figs. 2 and A1). The size distributions used to convert modeled aerosol mass to number were devel- 

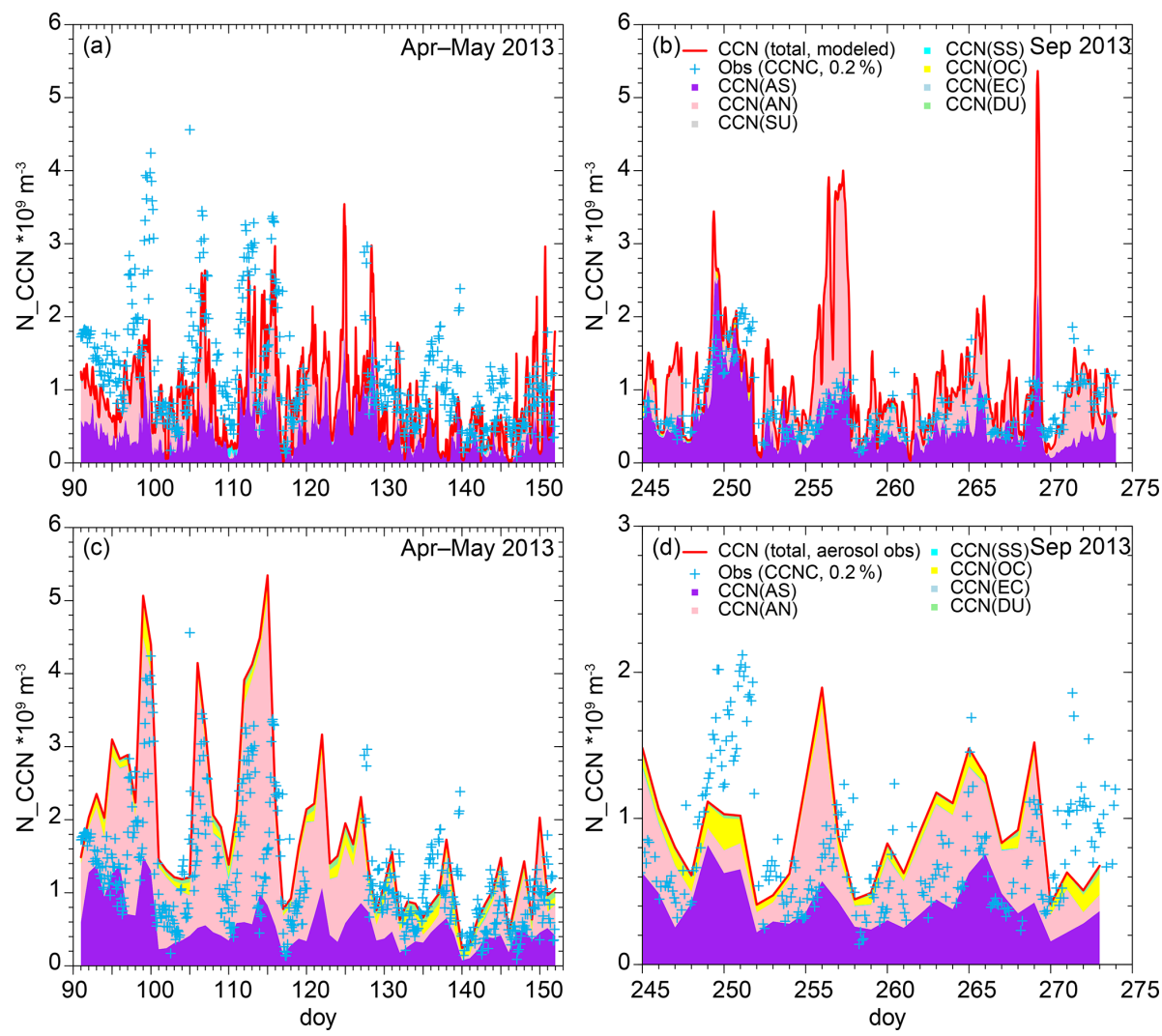

Figure 2. Simulated and measured CCN number concentrations in Melpitz at a supersaturation of $0.2 \%$ during the two HOPE campaigns (April to May and September 2013). Panels (a) and (b) show the CCN number concentrations resulting from the simulated aerosol concentrations, while panels $(\mathbf{c})$ and $(\mathbf{d})$ show the $\mathrm{CCN}$ numbers resulting from measured aerosol concentrations using the same $\mathrm{CCN}$ parametrization. The colors represent the contributions to $\mathrm{CCN}$ of different species. The blue crosses indicate the CCN number concentrations using the CCNC. Please note the different time resolution for the observations and the different scale for the CCN number concentration in (d).

oped with data at Melpitz. They are able to represent the average total particle number concentration at $100 \mathrm{~nm}$ (Fig. 3c in Hande et al., 2016). For particles larger than $110 \mathrm{~nm}$, the observed total particle number concentration is underestimated by $10 \%$. However, the number concentration of particles larger than $80 \mathrm{~nm}$ is underestimated by $35 \%$. Hence, the underestimated modeled number concentration of aerosol particles in the size range between 80 and $110 \mathrm{~nm}$ in diameter is likely the main reason for the different behavior between the N_CCN $0.2 \%$ to N_CN $110 \mathrm{~nm}$ ratio and the N_CCN $0.3 \%$ to N_CN $80 \mathrm{~nm}$ ratio. From Fig. 4, it can be seen that there is no difference in the comparison to the observation between the spring and the fall episode. Hence, the different underestimation and overestimation of the $\mathrm{CCN}$ concentration between the spring and the fall episode seen in Figs. 2, 3, and A1 is more likely linked to uncertainties of the modeled aerosol mass than the assumptions made to derive $\mathrm{CCN}$.

Figure 5 shows the average N_CCN-to-N_CN ratio for five different supersaturations between $0.1 \%$ and $0.7 \%$ for a cutoff diameter of $40 \mathrm{~nm}$. It can be seen from this graph that at a low supersaturation of $0.1 \%$ only very few particles activate, whereas almost all particles activate at a high su- persaturation of $0.7 \%$. In the model, more of the available aerosol particles activate at the respective supersaturation, which is most pronounced in the medium range of supersaturations between $0.3 \%$ and $0.5 \%$. The assumed size distributions are known to lack particles that are much smaller and much larger than $100 \mathrm{~nm}$. Hence, for very low and high supersaturations, both the number of particles and the CCN concentration are similarly underestimated. For supersaturations in between, for which the critical size of activation is in the size range where the assumed size distribution matches the average observations quite well (i.e., around $100 \mathrm{~nm}$ ), the modeled CCN concentration is less underestimated on average.

\subsection{Evaluation of the vertical structure of $\mathrm{CCN}$}

In order to evaluate the vertical distribution of the $\mathrm{CCN}$ concentrations and investigate its change since the 1980s, the modeled vertical profiles are compared to measurements. Figure 6 compares the simulated and observed vertical profiles of the CCN number concentration for the two periods in 2013. Figure 6a shows the comparison to $\mathrm{CCN}$ derived 

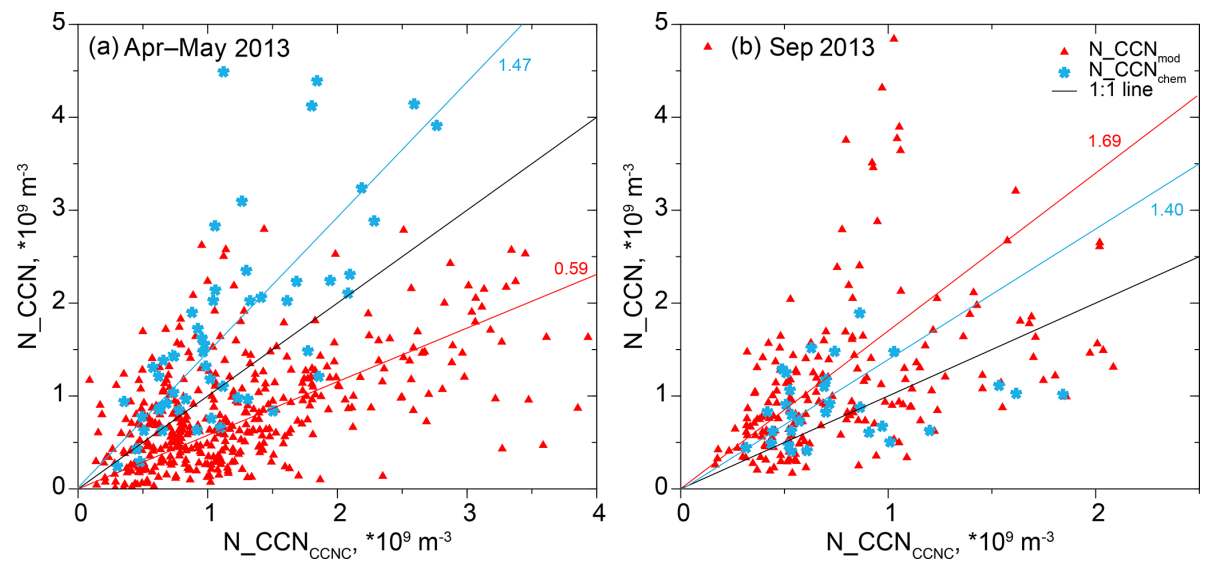

Figure 3. Comparison of derived and measured CCN number concentrations in Melpitz at a supersaturation of $0.2 \%$. Red triangles show results from the aerosol simulations, and blue stars show results from applying the CCN parameterization to the gravimetrically measured aerosol mass concentrations. The colored lines are the linear regressions. The slopes of the fits are given at the regression lines.
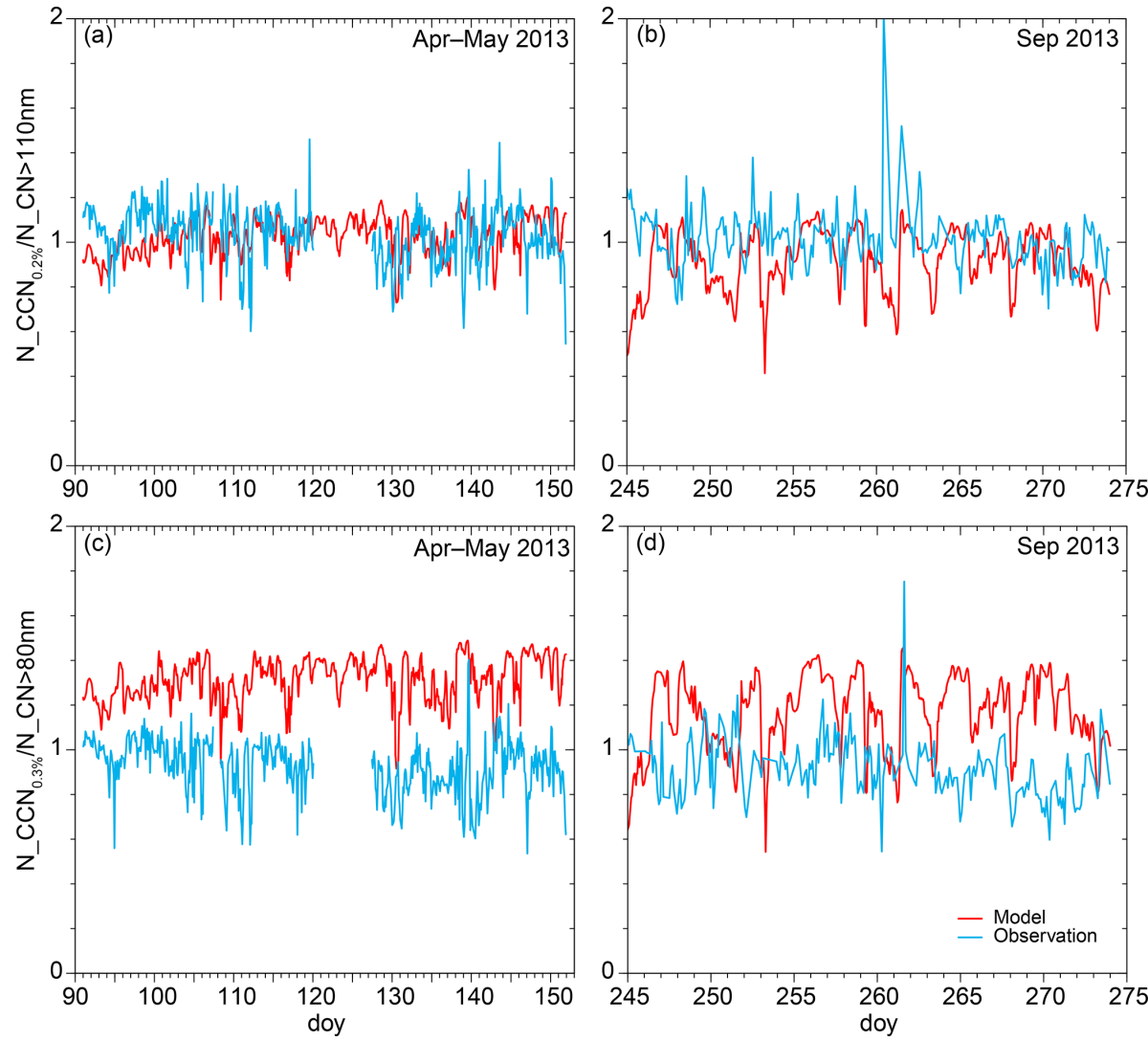

Figure 4. Comparison of the modeled and observed activated fraction (N_CCN/N_CN) at a supersaturation of $0.2 \%$ (a, b) and $0.3 \%$ (c, d), respectively. For the number of total $\mathrm{CN}$, the number concentration of $\mathrm{CN}>110 \mathrm{~nm}(\mathbf{a}, \mathbf{b})$ and $>80 \mathrm{~nm}(\mathbf{c}, \mathbf{d})$, respectively, was used.

from lidar observation during the spring period at Jülich, and Fig. $6 \mathrm{~b}$ shows the comparison to the in situ observations by the helicopter-based platform ACTOS during the fall period at Melpitz. Displayed are the median values, as well as the 0.25 and 0.75 quantiles. For the spring period and close to the ground, the average $\mathrm{CCN}$ number concentration is over- estimated by less than $50 \%$, which is in the range of the observation uncertainty of up to a factor of 2-3. However, up to a height of $\sim 1.3 \mathrm{~km}$, marking the average height of the boundary layer, the overestimation increases up to a factor of $\sim 2$. Nevertheless, the displayed $0.25-0.75$ quantile range still overlaps in the boundary layer. Above this height, the 
observed and modeled CCN concentrations start to decrease considerably, but this decrease is clearly stronger in the lidar observations. The model seems to transport too much aerosol mass into the free troposphere. In contrast to the model, the CCN number concentrations derived from the lidar are on average negligible at heights above $4 \mathrm{~km}$. Nevertheless, the variability of the observed $\mathrm{CCN}$ number concentrations is higher in the free troposphere. This is mainly an expression of increased detection uncertainty. The comparison to the in situ observations by ACTOS during the fall period displayed in Fig. 6b reveals a stronger overestimation close to the ground by a factor of $\sim 2$. Also, for this comparison, the modeled CCN number concentration does not decrease as strongly with height above the boundary layer $(\sim 1.5 \mathrm{~km})$, hence increasing the overestimation. Note that the larger variability of the median with height and the smaller $0.25-0.75$ quantile range is caused by the smaller sample size of only eight distinct cases compared to the $48 \mathrm{~d}$ with several hours of lidar observations during the spring period. Furthermore, the ACTOS observations have a general uncertainty of only $\sim 10 \%$. This therefore manifests the tendency of the model to overestimate the average $\mathrm{CCN}$ concentrations in the boundary layer by up to a factor of 2 and higher above the boundary layer. The general overestimation could be reduced by assuming different aerosol size distributions, which are used to convert modeled aerosol mass into aerosol number. However, the utilized size distributions were derived from data at Melpitz and any other size distribution would therefore be less justified. It can be expected that the size distribution is not constant in time and space as it is currently applied. Simulations that treat the aerosol in a sizeresolved manner, including aerosol microphysics, are a useful tool to provide more insight into the temporal and spatial variability of the aerosol size distribution and hence the $\mathrm{CCN}$ number concentration. However, due to the increased degrees of freedom and similar assumptions, such as the size distribution during the emission, the results are not necessarily more accurate. Overall, although the model tends to overestimate the average $\mathrm{CCN}$ concentrations, the modeled present-day $\mathrm{CCN}$ number concentration is in line with the observations, whereas the estimated profile for the 1980s is far outside today's observational range (see Figs. 6 and 7). This indicates the influence of anthropogenic air pollution on the $\mathrm{CCN}$ number.

\subsection{Present-day and historical vertical $\mathrm{CCN}$ profiles}

For each of the two periods, a temporally and spatially averaged vertical profile of the CCN concentration was calculated for the year 2013 and the mid-1980s scenario, which is displayed together with the $0.05,0.25,0.75$ and 0.95 quantiles in Fig. 7a-d. For the calculation, a vertical velocity of $1 \mathrm{~m} \mathrm{~s}^{-1}$ was assumed. This is an example of the CCN fields that are required as input for the ICON-LEM simulations within the $\mathrm{HD}(\mathrm{CP})^{2}$ project. In contrast to the previous anal-

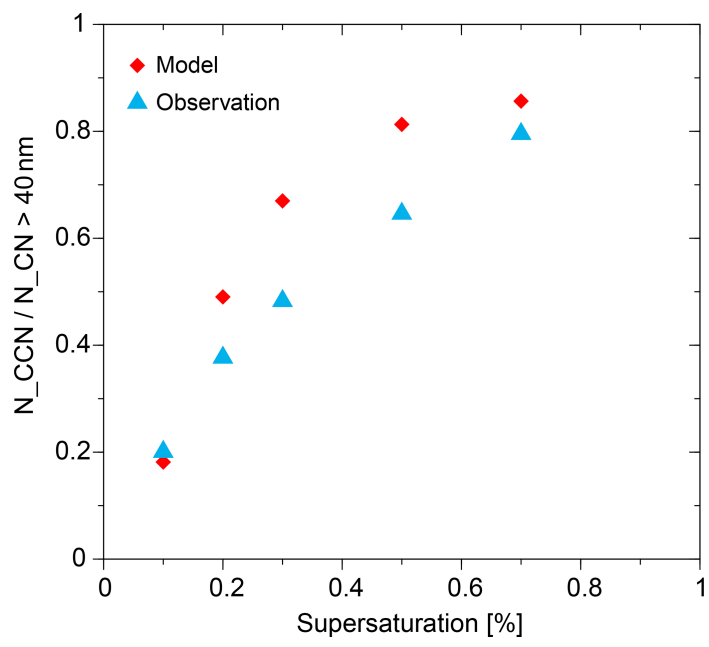

Figure 5. Simulated and observed fraction of CCN number concentration to the total number concentration of particles with a diameter larger than $40 \mathrm{~nm}$ (N_CCN/N_CN) as a function of supersaturation.

ysis, the applied supersaturation, and hence the critical size of activation, is not fixed but now results from the competition of the aerosol particles for the available water vapor. Therefore, the supersaturation and critical size of activation depend on the aerosol composition and vary temporally and spatially. The shape and values of the profiles show no major differences for the spring and fall episodes. Close to the ground, where aerosol particles are emitted, the number concentrations of $\mathrm{CCN}$ are higher than in the free troposphere. With increasing height, the number of aerosol particles and thus that of CCN is also decreasing. This is the case for both the 2013 and the mid-1980s scenario. In 2013, the concentrations are almost constant up to a height of $1 \mathrm{~km}$ (around $1.0 \times 10^{9} \mathrm{~m}^{-3}$ ) due to the well-mixed boundary layer and decrease above (Fig. 7a, b). This is less pronounced in the mid-1980s scenario (Fig. 7c, d), in which the concentrations close to the ground are much higher (around $3 \times 10^{9} \mathrm{~m}^{-3}$ ) and decrease almost immediately with height. At the top of the uppermost simulated layer $(8 \mathrm{~km})$, similar concentrations of $5 \times 10^{7}$ to $1 \times 10^{8} \mathrm{~m}^{-3}$ were found for both the presentday and peak aerosol scenario. Due to different vertical distribution of the aerosol constituents, the aerosol composition and hence aerosol hygroscopicity deviate between the mid1980s and 2013. Therefore, since Fig. 7 presents the CCN concentration for a fixed vertical velocity leading to variable supersaturations, the shape of the CCN profiles in the two scenarios differs.

Based on the $\mathrm{CCN}$ profiles, a scaling factor for the $\mathrm{CCN}$ concentration was calculated that varies with height (Fig. 7e, f). This scaling factor describes the difference in $\mathrm{CCN}$ number concentration between the past peak aerosol in the mid1980s and present-day conditions in Europe and is useful for sensitivity studies. The difference in the vertical profile of the CCN number concentrations between the 2013 and the mid- 


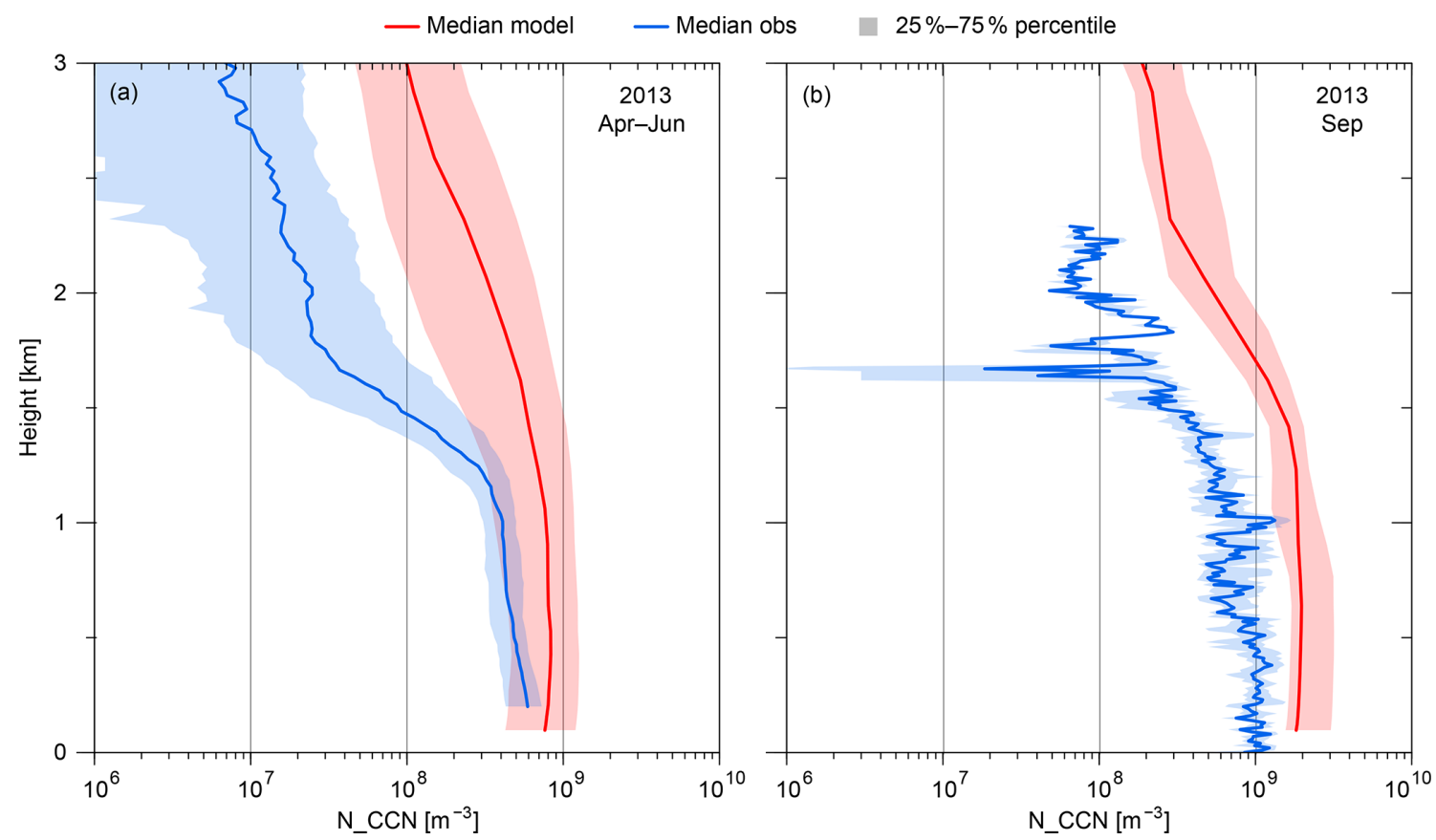

Figure 6. Comparison of the simulated vertical profiles of $\mathrm{CCN}$ number concentration (red) to profiles derived from observations (blue) of (a) lidar (April-May 2013) at Jülich, Germany, and (b) ACTOS (September 2013) at Melpitz, Germany. The CCN number concentrations were calculated or measured for a supersaturation of $0.2 \%$. The shading depicts the range between the 0.25 and the 0.75 quantiles. On 48 and 8 different days, 335 and 27 model profiles (instantaneous hourly output), which matched the time of observations, could be taken into account for the spring and fall period.

1980s scenarios is the reason for the curvature in the plot of the scaling factor at around $1 \mathrm{~km}$ height (Fig. $7 \mathrm{e}, \mathrm{f})$ because at this height the concentrations in the 2013 simulations also start to decrease. The efficacy of pollution-reduction policies and the breakdown of industrial production in the former Eastern Bloc countries at the end of the 1980s becomes evident in terms of CCN. Close to the ground, a factor of around 2 was found. The relative difference between mid-1980s and 2013 is most pronounced in the height between 2 and $5 \mathrm{~km}$, where a scaling factor of up to 3.5 was found. In the upper troposphere, the scaling factor decreases to around 1 , which means there is no difference between the 1980s and presentday concentrations.

\section{Summary and conclusions}

The CCN number concentrations from different simulation estimates and observation techniques were compared for two periods of the HOPE field experiments in Germany in spring and fall 2013. Based on simulations of the mass concentrations of different aerosol species (ammonium sulfate, ammonium nitrate, sulfate, organic carbon, elemental carbon, sea salt, and mineral dust) using the regional chemistry transport model COSMO-MUSCAT, the CCN number was computed offline using a state-of-the-art parameterization for cloud droplet activation. The resulting $\mathrm{CCN}$ number concen- trations were compared to direct $\mathrm{CCN}$ measurements with a $\mathrm{CCN}$ counter, $\mathrm{CCN}$ number concentrations derived from applying the activation parameterization to gravimetrically measured aerosol mass concentrations, and vertical profiles derived from lidar observations and helicopter-borne in situ measurements. In addition, CCN number concentrations representative of the mid-1980s, when the anthropogenic air pollution in central Europe was highest, for the two periods were computed based on the COSMO-MUSCAT simulations of the year 2013. Comparing the results for the year 2013 and the mid-1980s scenario allows us to investigate the impact of anthropogenic air pollution and the potential of the applied reduction measures on the atmospheric $\mathrm{CCN}$ budget.

At the ground and averaged over the full investigation period, the model-derived $\mathrm{CCN}$ concentrations (for a supersaturation of $0.2 \%$ ) were about $16 \%$ lower than the directly measured CCN concentrations and $37 \%$ lower than the CCN concentrations derived from aerosol mass measurements. Hence, the model and observations agree well for the longterm average. However, the deviations were different for the individual periods, with $29 \%$ underestimation of the measured $\mathrm{CCN}$ concentrations by the model in the spring period and $37 \%$ overestimation for the fall period. Discrepancies between observed and modeled CCN concentrations likely resulted mostly from uncertainties in the modeled aerosol mass and composition, as well as the assumptions for the 

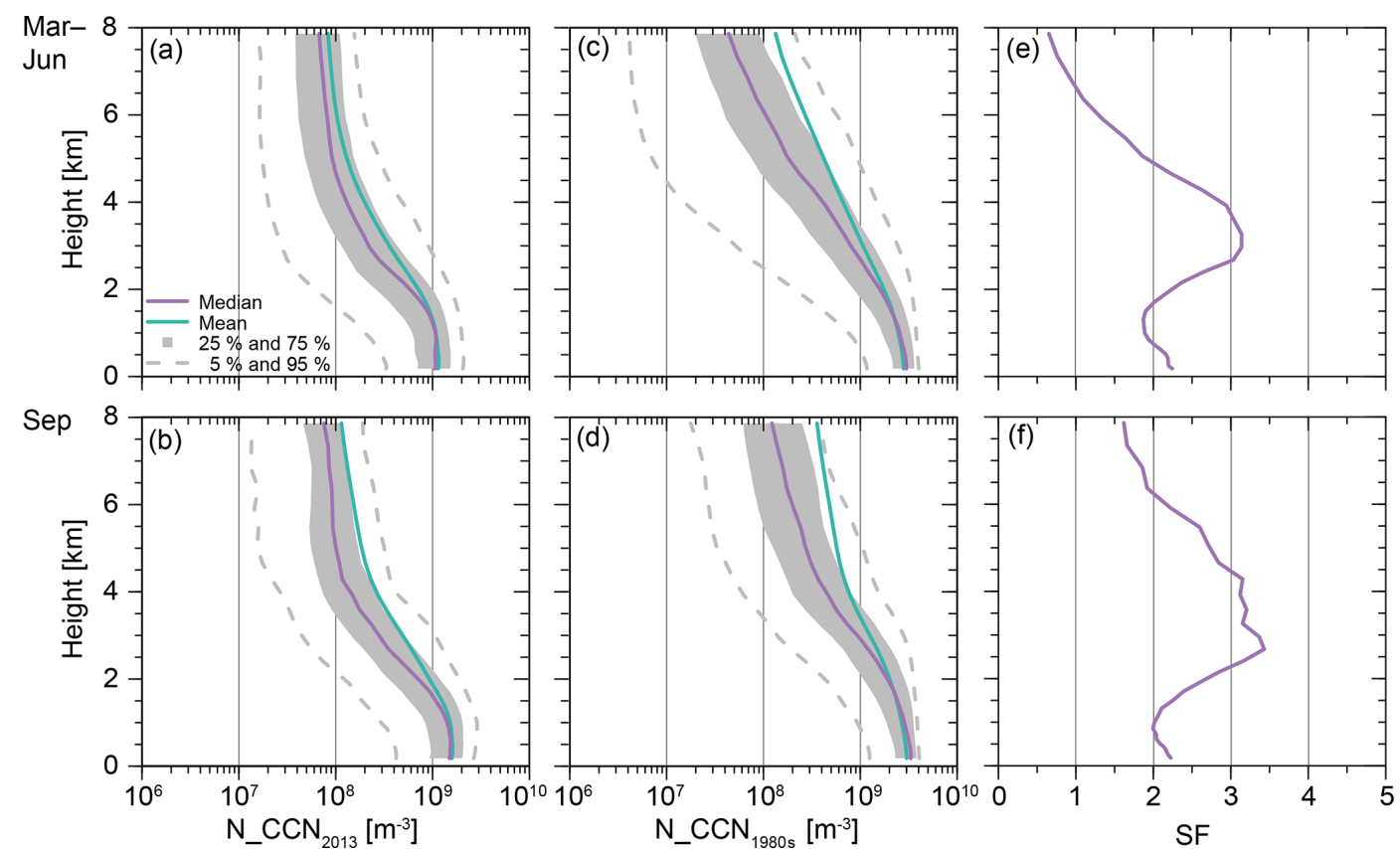

Figure 7. Spatially and temporally averaged vertical profile of the CCN number concentration as computed by COSMO-MUSCAT for the spring and fall period in 2013 (a, b), the estimation for the respective mid-1980s peak aerosol scenario (c, d), and the scaling factor (SF) for the two scenarios ( $\mathrm{SF}=\mathrm{N}_{-} \mathrm{CCN}_{1980 s} / \mathrm{N}_{-} \mathrm{CCN}_{2013}$; e and $\mathbf{f}$ ). For the calculation of the CCN number concentration, a vertical velocity of $1 \mathrm{~ms}^{-1}$ was assumed.

conversion from particle mass into number size distributions, which do not allow for the necessary flexibility to consider weather and transport-related heterogeneity. The comparison of the ratio of the $\mathrm{CCN}$ number concentration and the total particle number of particles larger than $110 \mathrm{~nm}$ in diameter shows a good agreement between model and observation for $0.2 \%$ supersaturation. However, for supersaturations between $0.2 \%$ and $0.7 \%$ and smaller threshold sizes to define CN (e.g., particles larger than $40 \mathrm{~nm}$ ), the model overestimates the activated particle fraction. Since the assumed prescribed size distributions were developed to correctly predict the average number of accumulation mode particles, which are the most relevant for deriving $\mathrm{CCN}$ number concentrations, the number of particles smaller than $\sim 100 \mathrm{~nm}$ is very likely underrepresented. As a nonlinear process, aerosol activation depends strongly on the current ambient aerosol size distribution, which can vary considerably both temporally and spatially. Hence, the application of fixed size distributions in order to convert modeled aerosol mass to number concentrations is a source of uncertainty, which might only cancel out for long-term averages.

At the measurement station Melpitz, Germany, the modelderived average CCN concentration for the mid-1980s scenario was more than 5 times higher than for the year 2013. The underlying aerosol load of the 1980s scenario is expected to be reasonable since a comparison of modeled to satellite-based aerosol optical depth (Costa-Surós et al., 2020) showed good agreement on average. Again, the appli- cation of fixed prescribed parameters for the number size distributions likely is a source of uncertainty since the aerosol size distributions in 2013 and the 1980s were not necessarily similar.

Within the boundary layer, the simulated vertical profiles of the present-day $\mathrm{CCN}$ concentration are within the variability range of the $\mathrm{CCN}$ derived from lidar measurements but do deviate from the in situ helicopter-borne $\mathrm{CCN}$ measurements outside their $0.25-0.75$ quantile range (and up to a factor of 2 for the median). The strong decrease in the observed CCN concentrations above the boundary layer could not be met by the model, hence it strongly overestimates the $\mathrm{CCN}$ concentration in the free troposphere. The mid-1980s scenario, however, has much larger CCN number concentration far outside the variability range of the present-day observations.

By comparing the CCN concentrations modeled for the year 2013 and the mid-1980s scenario, the effect of strict emission reduction policies and reorganization of industrial production in eastern Europe after 1990 becomes apparent. A domain- and time-averaged vertically resolved scaling factor for the CCN concentration between the year 2013 and the mid-1980s was computed, which is well suited for application in model sensitivity studies, in particular for studies that do not consider aerosol transport and chemistry explicitly. The scaling factor for estimating the $\mathrm{CCN}$ concentrations during the 1980s from current simulations is not vertically homogeneous. Close to the ground, a scaling factor of 2 was determined, increasing to 3.5 between 2 and $5 \mathrm{~km}$ height. To- 
wards the upper troposphere at around $8 \mathrm{~km}$ height, the scaling factor decreases again to 1 . The vertical variability of the $\mathrm{CCN}$ scaling factor is caused by the changed chemical composition of the aerosol due to the 1980s emission estimates. Especially the height range of up to $5 \mathrm{~km}$, where a very high CCN number concentration during the 1980s was found, is important for cloud and precipitation formation in the midlatitudes (e.g., Lebo, 2014; Marinescu et al., 2017). A significantly higher number of $\mathrm{CCN}$ points to large differences in the cloud droplet number concentration, the radiative properties of the clouds, and the precipitation probability during that time. The analysis of the radiative impacts including effects on cloud cover and albedo effects should be subject of future studies. 


\section{Appendix A}
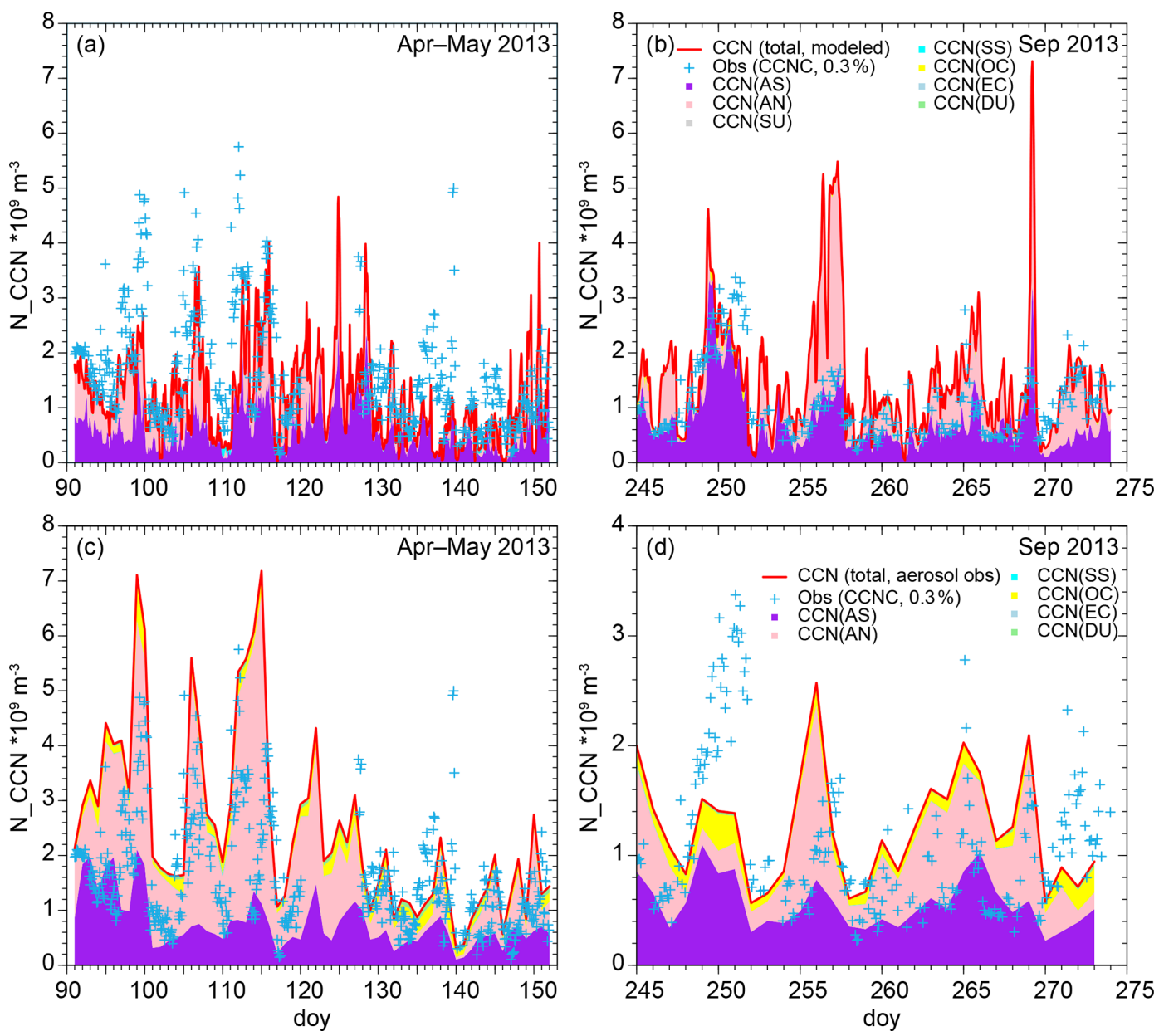

Figure A1. Simulated and measured CCN number concentrations in Melpitz at a supersaturation of $0.3 \%$ during the two HOPE campaigns (April to May and September 2013). Panels (a) and (b) show the CCN number concentrations resulting from the simulated aerosol concentrations, while panels (c) and (d) show the $\mathrm{CCN}$ numbers resulting from measured aerosol concentrations using the same CCN parametrization. The colors represent the contributions to $\mathrm{CCN}$ of different species. The blue crosses indicate the $\mathrm{CCN}$ number concentrations using the CCNC. Please note the different time resolution for the observations and the different scale for the CCN number concentration in plot (d). 
Data availability. The long-term Polly lidar level-0 data are plotted online at http://polly.rsd.tropos.de (TROPOS remote sensing group, 2020); raw data are available at TROPOS upon request (polly@tropos.de) via ftp. It is a future goal to make all of the data accessible through the ACTRIS data portal https: //actris.nilu.no/ (ACTRIS, 2020). CCN observations are already available in the ACTRIS database (https://actris.nilu.no/, last access: 16 July 2020) and via ftp://ebas-secondary-data.nilu.no/pub/ ebas-secondary-data/Schmale_et_2016/ (Henning and Schmale, 2016). The chemical measurements $\left(\mathrm{PM}_{10}\right)$ are available at TROPOS upon request (spindler@tropos.de). The COSMO-MUSCAT model output data are archived at TROPOS and are available upon request (ina.tegen@tropos.de).

Author contributions. CG ran the COSMO-MUSCAT model working with IT and $\mathrm{BH}$ and performed the aerosol evaluation and $\mathrm{CCN}$ concentration calculation. RS joined during the analysis and coordinated the revision. SH provided the CCNC measurements, HB provided the lidar-derived CCN profiles, and GS obtained the chemical measurements and analysis. CG and RS prepared the manuscript with contributions from all co-authors.

Competing interests. The authors declare that they have no conflict of interest.

Acknowledgements. The simulation data were generated using Copernicus Atmosphere Monitoring Service Information. The authors wish to thank Luke Hande for providing a version of CCN calculation code, which served as the basis for the estimations shown here. We also acknowledge the good cooperation and support from the German Weather Service (Deutscher Wetterdienst, DWD) and the high-performance computing center in Jülich. Furthermore, the authors acknowledge support from ACTRIS under grant agreement no. 262254 of the European Union Seventh Framework Programme (FP7/2007-2013).

Financial support. This work was funded by the Federal Ministry of Education and Research in Germany (BMBF) through the research program "High Definition Clouds and Precipitation for Climate Prediction - $\mathrm{HD}(\mathrm{CP})^{2}$ " (grant nos. 01LK1503F, 01LK1502I, 01LK1209C, and 01LK1212C).

The publication of this article was funded by the Open Access Fund of the Leibniz Association.

Review statement. This paper was edited by Markus Petters and reviewed by two anonymous referees.

\section{References}

Abdul-Razzak, H. and Ghan, S.: A parametreization of aerosol activation: 2. Multiple aerosol types, J. Geophys. Res., 105, 68376844, 2000.

Abdul-Razzak, H., Ghan, S., and Rivera-Carpio, C.: A parametreization of aerosol activation: 1 . Single aerosol types, J. Geophys. Res., 103, 6123-6131, 1998.

Aerosols, Clouds, and Trace gases Research InfraStructure Network (ACTRIS): ACTRIS Data Centre, available at: https://actris.nilu. no/, last access 16 July 2020.

Baars, H., Kanitz, T., Engelmann, R., Althausen, D., Heese, B., Komppula, M., Preißler, J., Tesche, M., Ansmann, A., Wandinger, U., Lim, J.-H., Ahn, J. Y., Stachlewska, I. S., Amiridis, V., Marinou, E., Seifert, P., Hofer, J., Skupin, A., Schneider, F., Bohlmann, S., Foth, A., Bley, S., Pfüller, A., Giannakaki, E., Lihavainen, H., Viisanen, Y., Hooda, R. K., Pereira, S. N., Bortoli, D., Wagner, F., Mattis, I., Janicka, L., Markowicz, K. M., Achtert, P., Artaxo, P., Pauliquevis, T., Souza, R. A. F., Sharma, V. P., van Zyl, P. G., Beukes, J. P., Sun, J., Rohwer, E. G., Deng, R., Mamouri, R.-E., and Zamorano, F.: An overview of the first decade of Polly ${ }^{N E T}$ : an emerging network of automated Raman-polarization lidars for continuous aerosol profiling, Atmos. Chem. Phys., 16, 5111-5137, https://doi.org/10.5194/acp16-5111-2016, 2016.

Baars, H., Seifert, P., Engelmann, R., and Wandinger, U.: Target categorization of aerosol and clouds by continuous multiwavelength-polarization lidar measurements, Atmos. Meas. Tech., 10, 3175-3201, https://doi.org/10.5194/amt-103175-2017, 2017.

Bangert, M., Kottmeier, C., Vogel, B., and Vogel, H.: Regional scale effects of the aerosol cloud interaction simulated with an online coupled comprehensive chemistry model, Atmos. Chem. Phys., 11, 4411-4423, https://doi.org/10.5194/acp-114411-2011, 2011.

Bègue, N., Tulet, P., Pelon, J., Aouizerats, B., Berger, A., and Schwarzenboeck, A.: Aerosol processing and CCN formation of an intense Saharan dust plume during the EUCAARI 2008 campaign, Atmos. Chem. Phys., 15, 3497-3516, https://doi.org/10.5194/acp-15-3497-2015, 2015.

Boucher, O., Randall, D., Artaxo, P., Bretherton, C., Feingold, G., Forster, P., Kerminen, V.-M., Kondo, Y., Liao, H., Lohmann, U., Rasch, P., Satheesh, S., Sherwood, S., X., B. S., and Zhang: Clouds and Aerosols, in: Climate Change 2013: The Physical Science Basis. Contribution of Working Group I to the Fifth Assessment Report of the Intergovernmental Panel on Climate Change, Cambridge Univ Press, New York, 2013.

Bühl, J., Seifert, P., Wandinger, U., Baars, H., Kanitz, T., Schmidt, J., Myagkov, A., Engelmann, R., Skupin, A., Heese, B., Klepel, A., Althausen, D., and Ansmann, A.: LACROS: the Leipzig Aerosol and Cloud Remote Observations System, in: Remote Sensing of Clouds and the Atmosphere XVIII; and Optics in Atmospheric Propagation and Adaptive Systems XVI, edited by: Comeron, A., Kassianov, E. I., Schäfer, K., Stein, K., and Gonglewski, J. D., vol. 8890, 1-6, International Society for Optics and Photonics, SPIE, https://doi.org/10.1117/12.2030911, 2013.

Costa-Surós, M., Sourdeval, O., Acquistapace, C., Baars, H., Carbajal Henken, C., Genz, C., Hesemann, J., Jimenez, C., König, M., Kretzschmar, J., Madenach, N., Meyer, C. I., Schröd- 
ner, R., Seifert, P., Senf, F., Brueck, M., Cioni, G., Engels, J. F., Fieg, K., Gorges, K., Heinze, R., Siligam, P. K., Burkhardt, U., Crewell, S., Hoose, C., Seifert, A., Tegen, I., and Quaas, J.: Detection and attribution of aerosol-cloud interactions in large-domain large-eddy simulations with the ICOsahedral Non-hydrostatic model, Atmos. Chem. Phys., 20, 5657-5678, https://doi.org/10.5194/acp-20-5657-2020, 2020.

Dipankar, A., Stevens, B., Heinze, R., Moseley, C., Zängl, G., Giorgetta, M., and Brdar, S.: Large eddy simulation using the general circulation model ICON, J. Adv. Model. Earth Sy., 7, 963-986, 2015.

Duplissy, J., DeCarlo, P. F., Dommen, J., Alfarra, M. R., Metzger, A., Barmpadimos, I., Prevot, A. S. H., Weingartner, E., Tritscher, T., Gysel, M., Aiken, A. C., Jimenez, J. L., Canagaratna, M. R., Worsnop, D. R., Collins, D. R., Tomlinson, J., and Baltensperger, U.: Relating hygroscopicity and composition of organic aerosol particulate matter, Atmos. Chem. Phys., 11, 11551165, https://doi.org/10.5194/acp-11-1155-2011, 2011.

Düsing, S., Wehner, B., Seifert, P., Ansmann, A., Baars, H., Ditas, F., Henning, S., Ma, N., Poulain, L., Siebert, H., Wiedensohler, A., and Macke, A.: Helicopter-borne observations of the continental background aerosol in combination with remote sensing and ground-based measurements, Atmos. Chem. Phys., 18, 1263-1290, https://doi.org/10.5194/acp-18-1263-2018, 2018.

EMEP: European Monitoring and Evaluation Programme, available at: http://www.emep.int/ (last access: 16 July 2020), 2009.

Engelmann, R., Kanitz, T., Baars, H., Heese, B., Althausen, D., Skupin, A., Wandinger, U., Komppula, M., Stachlewska, I. S., Amiridis, V., Marinou, E., Mattis, I., Linné, H., and Ansmann, A.: The automated multiwavelength Raman polarization and water-vapor lidar Polly XT: the neXT generation, Atmos. Meas. Tech., 9, 1767-1784, https://doi.org/10.5194/amt-9-1767-2016, 2016.

Engler, C., Rose, D., Wehner, B., Wiedensohler, A., Brüggemann, E., Gnauk, T., Spindler, G., Tuch, T., and Birmili, W.: Size distributions of non-volatile particle residuals $\left(D_{\mathrm{p}}<800 \mathrm{~nm}\right)$ at a rural site in Germany and relation to air mass origin, Atmos. Chem. Phys., 7, 5785-5802, https://doi.org/10.5194/acp-7-57852007, 2007.

Fanourgakis, G. S., Kanakidou, M., Nenes, A., Bauer, S. E., Bergman, T., Carslaw, K. S., Grini, A., Hamilton, D. S., Johnson, J. S., Karydis, V. A., Kirkevåg, A., Kodros, J. K., Lohmann, U., Luo, G., Makkonen, R., Matsui, H., Neubauer, D., Pierce, J. R., Schmale, J., Stier, P., Tsigaridis, K., van Noije, T., Wang, H., Watson-Parris, D., Westervelt, D. M., Yang, Y., Yoshioka, M., Daskalakis, N., Decesari, S., Gysel-Beer, M., Kalivitis, N., Liu, X., Mahowald, N. M., Myriokefalitakis, S., Schrödner, R., Sfakianaki, M., Tsimpidi, A. P., Wu, M., and Yu, F.: Evaluation of global simulations of aerosol particle and cloud condensation nuclei number, with implications for cloud droplet formation, Atmos. Chem. Phys., 19, 8591-8617, https://doi.org/10.5194/acp19-8591-2019, 2019.

Feingold, G., Yang, S., Hardesty, R. M., and Cotton, W. R.: Feasibility of Retrieving Cloud Condensation Nucleus Properties from Doppler Cloud Radar, Microwave Radiometer, and Lidar, J. Atmos. Ocean. Tech., 15, 1188-1195, https://doi.org/10.1175/15200426(1998)015<1188:FORCCN>2.0.CO;2, 1998.
Friedman, B., Zelenyuk, A., Beranek, J., Kulkarni, G., Pekour, M., Gannet Hallar, A., McCubbin, I. B., Thornton, J. A., and Cziczo, D. J.: Aerosol measurements at a high-elevation site: composition, size, and cloud condensation nuclei activity, Atmos. Chem. Phys., 13, 11839-11851, https://doi.org/10.5194/acp-13-118392013, 2013.

Ghan, S., Laulainen, N., Easter, R., Wagener, R., Nemesure, S., Chapman, E., Zhang, Y., and Leung, R.: Evaluation of aerosol direct radiative forcing in MIRAGE, J. Geophys. Res., 106, 52955316, 2001.

Ghan, S., Rissman, T., Elleman, R., Ferrare, R., Turner, D., Flynn, C., Wang, J., Ogren, J., Hudson, J., Jonsson, H., VanReken, T., Flagan, R., and Seinfeld, J.: Use of in situ cloud condensation nuclei, extinction, and aerosol size distribution measurements to test a method for retrieving cloud condensation nuclei profiles from surface measurements, J. Geophys. Res., 111, D05S10, https://doi.org/10.1029/2004JD005752, 2006.

Gysel, M. and Stratmann, F.: WP3 - NA3: In-situ chemical, physical and optical properties of aerosols, available at: http://www.actris.net/Publications/ACTRISQualityStandards/ tabid/11271/language/en-GB/Default.aspx (last access: 16 July 2020), 2013.

Hammer, E., Bukowiecki, N., Gysel, M., Jurányi, Z., Hoyle, C. R., Vogt, R., Baltensperger, U., and Weingartner, E.: Investigation of the effective peak supersaturation for liquid-phase clouds at the high-alpine site Jungfraujoch, Switzerland (3580 m a.s.1.), Atmos. Chem. Phys., 14, 1123-1139, https://doi.org/10.5194/acp14-1123-2014, 2014.

Hande, L. B., Engler, C., Hoose, C., and Tegen, I.: Parameterizing cloud condensation nuclei concentrations during HOPE, Atmos. Chem. Phys., 16, 12059-12079, https://doi.org/10.5194/acp-1612059-2016, 2016.

Heinold, B., Tegen, I., Schepanski, K., Tesche, M., Esselborn, M., Freudenthaler, V., Gross, S., Kandler, K., Knippertz, P., and Müller, D.: Regional modeling of Saharan dust and biomassburning smoke, Tellus B, 63, 781-799, 2011.

Heinze, R., Moseley, C., Böske, L. N., Muppa, S. K., Maurer, V., Raasch, S., and Stevens, B.: Evaluation of large-eddy simulations forced with mesoscale model output for a multi-week period during a measurement campaign, Atmos. Chem. Phys., 17, 7083-7109, https://doi.org/10.5194/acp-17-7083-2017, 2017.

Henning, S. and Schmale, J.: CCN_DMT_cloud_ condensation_nuclei_counter_station_Melpitz_ACTRIS_01.01.2012_ 31.12.2014.nc, syn_MEL_CCN_20160916.v1, ACTRIS, EBAS database, available at: ftp://ebas-secondary-data.nilu.no/pub/ ebas-secondary-data/Schmale_et_2016/ (last access: 16 July 2020), 2016.

Henning, S., Wex, H., Hennig, T., Kiselev, A., Snider, J., Rose, D., Dusek, U., Frank, G., Pöschl, U., Kristensson, A., Bilde, M., Tillmann, R., Kiendler-Scharr, A., Mentel, T., Walter, S., Schneider, J., Wennrich, C., and Stratmann, F.: Soluble mass, hygroscopic growth, and droplet activation of coated soot particles during LACIS Experiment in November (LExNo), J. Geophys. Res., 115, D11206, https://doi.org/10.1029/2009JD012626, 2010.

Henning, S., Dieckmann, K., Ignatius, K., Schäfer, M., Zedler, P., Harris, E., Sinha, B., van Pinxteren, D., Mertes, S., Birmili, W., Merkel, M., Wu, Z., Wiedensohler, A., Wex, H., Herrmann, H., and Stratmann, F.: Influence of cloud processing on $\mathrm{CCN}$ activation behaviour in the Thuringian Forest, Ger- 
many during HCCT-2010, Atmos. Chem. Phys., 14, 7859-7868, https://doi.org/10.5194/acp-14-7859-2014, 2014.

Hinneburg, D., Renner, E., and Wolke, R.: Formation of secondary inorganic aerosols by power plant emissions exhausted through cooling towers in Saxony, Environ. Sci. Pollut. Res., 16, 25-35, https://doi.org/10.1007/s11356-008-0081-5, 2009.

Hoppel, W. A., Dinger, J. E., and Ruskin, R. E.: Vertical Profiles of $\mathrm{CCN}$ at Various Geographical Locations, J. Atmos. Sci., 30, 1410-1420, https://doi.org/10.1175/15200469(1973)030<1410:VPOCAV>2.0.CO;2, 1973.

Inness, A., Ades, M., Agustí-Panareda, A., Barré, J., Benedictow, A., Blechschmidt, A.-M., Dominguez, J. J., Engelen, R., Eskes, H., Flemming, J., Huijnen, V., Jones, L., Kipling, Z., Massart, S., Parrington, M., Peuch, V.-H., Razinger, M., Remy, S., Schulz, M., and Suttie, M.: The CAMS reanalysis of atmospheric composition, Atmos. Chem. Phys., 19, 3515-3556, https://doi.org/10.5194/acp-19-3515-2019, 2019.

Jimenez, J., Canagaratna, M., Donahue, N., Prevot, A., Zhang, Q., Kroll, J., DeCarlo, P., Allan, J., Coe, H., Ng, N., Aiken, A., Docherty, K., Ulbrich, I., Grieshop, A., Robinson, A., Duplissy, J., Smith, J., Wilson, K., Lanz, V., Hueglin, C., Sun, Y., Tian, J., Laaksonen, A., Raatikainen, T., Rautiainen, J., Vaattovaara, P., Ehn, M., Kulmala, M., Tomlinson, J., Collins, D., Cubison, M., Dunlea, E., Huffman, J., Onasch, T., Alfarra, M., Williams, P., Bower, K., Kondo, Y., Schneider, J., Drewnick, F., Borrmann, S., Weimer, S., Demerjian, K., Salcedo, D., Cottrell, L., Griffin, R., Takami, A., Miyoshi, T., Hatakeyama, S., Shimono, A., Sun, J., Zhang, Y., Dzepina, K., Kimmel, J., Sueper, D., Jayne, J., Herndon, S., Trimborn, A., Williams, L., Wood, E., Middlebrook, A., Kolb, C., Baltensperger, U., and Worsnop, D.: Evolution of Organic Aerosols in the Atmosphere, Science, 326, 15251529, 2009.

Köhler, H.: The nucleus in and the growth of hygroscopic droplets, T. Faraday Soc., 32, 1152-1161, 1936.

Lebo, Z. J.: The Sensitivity of a Numerically Simulated Idealized Squall Line to the Vertical Distribution of Aerosols, J. Atmos. Sci., 71, 4581-4596, https://doi.org/10.1175/JAS-D-14-0068.1, 2014.

Lv, M., Wang, Z., Li, Z., Luo, T., Ferrare, R., Liu, D., Wu, D., Mao, J., Wan, B., Zhang, F., and Wang, Y.: Retrieval of Cloud Condensation Nuclei Number Concentration Profiles From Lidar Extinction and Backscatter Data, J. Geophys. Res.-Atmos., 123, 6082-6098, https://doi.org/10.1029/2017JD028102, 2018.

Macke, A., Seifert, P., Baars, H., Barthlott, C., Beekmans, C., Behrendt, A., Bohn, B., Brueck, M., Bühl, J., Crewell, S., Damian, T., Deneke, H., Düsing, S., Foth, A., Di Girolamo, P., Hammann, E., Heinze, R., Hirsikko, A., Kalisch, J., Kalthoff, N., Kinne, S., Kohler, M., Löhnert, U., Madhavan, B. L., Maurer, V., Muppa, S. K., Schween, J., Serikov, I., Siebert, H., Simmer, C., Späth, F., Steinke, S., Träumner, K., Trömel, S., Wehner, B., Wieser, A., Wulfmeyer, V., and Xie, X.: The $\mathrm{HD}(\mathrm{CP})^{2} \mathrm{Ob}-$ servational Prototype Experiment (HOPE) - an overview, Atmos. Chem. Phys., 17, 4887-4914, https://doi.org/10.5194/acp17-4887-2017, 2017.

Majewski, D., Liermann, D., Prohl, P., Ritter, B., Buchhold, M., Hanisch, T., Paul, G., Wergen, W., and Baumgardner, J.: The Operational Global Icosahedral-Hexagonal Gridpoint Model GME: Description and High-Resolution Tests,
Mon. Weather Rev., 130, 319-338, https://doi.org/10.1175/15200493(2002)130<0319:TOGIHG>2.0.CO;2, 2002.

Mamouri, R.-E. and Ansmann, A.: Potential of polarization lidar to provide profiles of $\mathrm{CCN}$ - and INP-relevant aerosol parameters, Atmos. Chem. Phys., 16, 5905-5931, https://doi.org/10.5194/acp-16-5905-2016, 2016.

Marinescu, P. J., van den Heever, S. C., Saleeby, S. M., Kreidenweis, S. M., and DeMott, P. J.: The Microphysical Roles of Lower-Tropospheric versus Midtropospheric Aerosol Particles in Mature-Stage MCS Precipitation, J. Atmos. Sci., 74, 3657-3678, https://doi.org/10.1175/JAS-D-16-0361.1, 2017.

Niedermeier, D., Wex, H., Voigtländer, J., Stratmann, F., Brüggemann, E., Kiselev, A., Henk, H., and Heintzenberg, J.: LACISmeasurements and parameterization of sea-salt particle hygroscopic growth and activation, Atmos. Chem. Phys., 8, 579-590, https://doi.org/10.5194/acp-8-579-2008, 2008.

Petters, M. D. and Kreidenweis, S. M.: A single parameter representation of hygroscopic growth and cloud condensation nucleus activity, Atmos. Chem. Phys., 7, 1961-1971, https://doi.org/10.5194/acp-7-1961-2007, 2007.

Poulain, L., Spindler, G., Birmili, W., Plass-Dülmer, C., Wiedensohler, A., and Herrmann, H.: Seasonal and diurnal variations of particulate nitrate and organic matter at the IfT research station Melpitz, Atmos. Chem. Phys., 11, 12579-12599, https://doi.org/10.5194/acp-11-12579-2011, 2011.

Roberts, G. and Nenes, A.: A continuous-flow streamwise thermalgradient CCN chamber for atmospheric measurements, Aerosol Sci. Technol., 39, 206-221, 2005.

Schmale, J., Henning, S., Henzing, B., Keskinen, H., Sellegri, K., Ovadnevaite, J., Bougiatioti, A., Kalivitis, N., Stavroulas, L., Jefferson, A., Park, M., Schlag, P., Kristensson, A., Iwamotol, Y., Pringle, K., Reddington, C., Aalto, P., Aijala, M., Baltensperger, U., Bialek, J., Birmili, W., Bukowiecki, N., Ehn, M., Fjaeraa, A., Fiebig, M., Frank, G., Frohlich, R., Frumau, A., Furuyals, M., E. Hammerl', E. H., Heikkinen, L., Herrmann, E., Holzinger, R., Hyonols, H., Kanakidoug, M., Kiendler-Scharr, A., Kinouchi, K., Kos, G., Kulmala, M., Mihalopoulos, N., Motos, G., Nenes, A., O’Dowd, C., Paramonov, M., Petaja, T., Picard, D., Poulain, L., Prevot, A., Slowik, J., Sonntag, A., Swietlicki, E., Svenningsson, B., Tsurumaru, H., Wiedensohler, A., Wittbom, C., Ogren, J., Matsuki, A., Yum, S., Myhre, C., Carslaw, K., Stratmann, F., and Gysel, M.: Data Descriptor: Collocated observations of cloud condensation nuclei, particle size distributions, and chemical composition, Sci. Data, 4, 170003, https://doi.org/10.1038/sdata.2017.3, 2017.

Schmale, J., Baccarini, A., Thurnherr, I., Henning, S., Efraim, A., Regayre, L., Bolas, C., Hartmann, M., Welti, A., Lehtipalo, K., Aemisegger, F., Tatzelt, C., Landwehr, S., Modini, R. L., Tummon, F., Johnson, J. S., Harris, N., Schnaiter, M., Toffoli, A., Derkani, M., Bukowiecki, N., Stratmann, F., Dommen, J., Baltensperger, U., Wernli, H., Rosenfeld, D., Gysel-Beer, M., and Carslaw, K. S.: Overview of the Antarctic Circumnavigation Expedition: Study of Preindustrial-like Aerosols and Their Climate Effects (ACE-SPACE), B. Am. Meteorol. Soc., 100, 2260-2283, https://doi.org/10.1175/BAMS-D-18-0187.1, 2019.

Seifert, A. and Beheng, K.: A two-moment cloud microphysics parameterization for mixed-phase clouds. Part 1: Model description, Meteorol. Atmos. Phys., 92, 45-66, https://doi.org/10.1007/s00703-005-0112-4, 2006. 
Seinfeld, J. H. and Pandis, S. N.: Atmospheric Chemistry and Physics, Johl Wiley \& Sons, Inc., New York, Chichester, Weinheim, Brisbane, Singapore, Toronto, 1326 pp., 1998.

Shinozuka, Y., Clarke, A. D., Nenes, A., Jefferson, A., Wood, R., McNaughton, C. S., Ström, J., Tunved, P., Redemann, J., Thornhill, K. L., Moore, R. H., Lathem, T. L., Lin, J. J., and Yoon, Y. J.: The relationship between cloud condensation nuclei (CCN) concentration and light extinction of dried particles: indications of underlying aerosol processes and implications for satellitebased CCN estimates, Atmos. Chem. Phys., 15, 7585-7604, https://doi.org/10.5194/acp-15-7585-2015, 2015.

Siebert, H., Franke, H., Lehmann, K., Maser, R., Saw, E. W., Schell, D., Shaw, R. A., and Wendisch, M.: Probing Finescale Dynamics and Microphysics of Clouds with HelicopterBorne Measurements, B. Am. Meteorol. Soc., 87, 1727-1738, https://doi.org/10.1175/BAMS-87-12-1727, 2006.

Simpson, D., Fagerli, H., Jonson, J. E., Tsyro, S., Wind, P., and Tuovinen, J.-K.: Transboundary Acidification, Eutrophication and Ground Level Ozone in Europe - PART I: Unified EMEP Model Description, Norwegian Meteorological Institute, emep status report 2003 edn., 2003.

Smith, S. J., van Aardenne, J., Klimont, Z., Andres, R. J., Volke, A., and Delgado Arias, S.: Anthropogenic sulfur dioxide emissions: 1850-2005, Atmos. Chem. Phys., 11, 1101-1116, https://doi.org/10.5194/acp-11-1101-2011, 2011.

Spindler, G., Gnauk, T., Grüner, A., Iinuma, Y., Müller, K., Scheinhardt, S., and Herrmann, H.: Size-segregated characterization of $\mathrm{PM}_{10}$ at the EMEP site Melpitz (Germany) using a five-stage impactor: a six year study, J. Atmos. Chem., 69, 127-157, 2012.

Spindler, G., Grüner, A., Müller, K., Schlimper, S., and Herrmann, H.: Long-term size-segregated particle $\left(\mathrm{PM}_{10}, \mathrm{PM}_{2.5}, \mathrm{PM}_{1}\right)$ characterization study at Melpitz - influence of air mass inflow, weather condition and season, J. Atmos. Chem., 70, 165-195, 2013.

Spracklen, D. V., Carslaw, K. S., Pöschl, U., Rap, A., and Forster, P. M.: Global cloud condensation nuclei influenced by carbonaceous combustion aerosol, Atmos. Chem. Phys., 11, 9067-9087, https://doi.org/10.5194/acp-11-9067-2011, 2011.

Squires, P. and Twomey, S.: A Comparison of Cloud Nucleus Measurements over Central North America and the Caribbean Sea, J. Atmos. Sci., 23, 401-404, https://doi.org/10.1175/15200469(1966)023<0401:ACOCNM>2.0.CO;2, 1966.

Dipu, S., Quaas, J., Wolke, R., Stoll, J., Mühlbauer, A., Sourdeval, O., Salzmann, M., Heinold, B., and Tegen, I.: Implementation of aerosol-cloud interactions in the regional atmosphere-aerosol model COSMO-MUSCAT(5.0) and evaluation using satellite data, Geosci. Model Dev., 10, 2231-2246, https://doi.org/10.5194/gmd-10-2231-2017, 2017.

Tørseth, K., Aas, W., Breivik, K., Fjæraa, A. M., Fiebig, M., Hjellbrekke, A. G., Lund Myhre, C., Solberg, S., and Yttri, K. E.: Introduction to the European Monitoring and Evaluation Programme (EMEP) and observed atmospheric composition change during 1972-2009, Atmos. Chem. Phys., 12, 5447-5481, https://doi.org/10.5194/acp-12-5447-2012, 2012.
TROPOS remote sensing group: World wide observations with the portable Raman lidar system, available at: http://polly.rsd.tropos. de, last access: 16 July 2020.

Twomey, S. and Squires, P.: The Influence of Cloud Nucleus Population on the Microstructure and Stability of Convective Clouds, Tellus, 11, 408-411, https://doi.org/10.1111/j.21533490.1959.tb00050.x, 1959.

Vestreng, V., Myhre, G., Fagerli, H., Reis, S., and Tarrasón, L.: Twenty-five years of continuous sulphur dioxide emission reduction in Europe, Atmos. Chem. Phys., 7, 3663-3681, https://doi.org/10.5194/acp-7-3663-2007, 2007.

Watson-Parris, D., Schutgens, N., Reddington, C., Pringle, K. J., Liu, D., Allan, J. D., Coe, H., Carslaw, K. S., and Stier, P.: In situ constraints on the vertical distribution of global aerosol, Atmos. Chem. Phys., 19, 11765-11790, https://doi.org/10.5194/acp-1911765-2019, 2019.

Wex, H., Petters, M. D., Carrico, C. M., Hallbauer, E., Massling, A., McMeeking, G. R., Poulain, L., Wu, Z., Kreidenweis, S. M., and Stratmann, F.: Towards closing the gap between hygroscopic growth and activation for secondary organic aerosol: Part $1-$ Evidence from measurements, Atmos. Chem. Phys., 9, 3987-3997, https://doi.org/10.5194/acp-9-3987-2009, 2009.

Wex, H., McFiggans, G., Henning, S., and Stratmann, F.: Influence of the external mixing state of atmospheric aerosol on derived CCN number concentrations, Geophys. Res. Lett., 37, L10805, https://doi.org/10.1029/2010GL043337, 2010.

Wex, H., Dieckmann, K., Roberts, G. C., Conrath, T., Izaguirre, M. A., Hartmann, S., Herenz, P., Schäfer, M., Ditas, F., Schmeissner, T., Henning, S., Wehner, B., Siebert, H., and Stratmann, F.: Aerosol arriving on the Caribbean island of Barbados: physical properties and origin, Atmos. Chem. Phys., 16, 14107-14130, https://doi.org/10.5194/acp-16-14107-2016, 2016.

Wiedensohler, A.: An approximation of the bipolar charge distribution for particles in the submicron size range, J. Aerosol Sci., 19, 387-389, https://doi.org/10.1016/0021-8502(88)90278-9, 1988.

Wolke, R., Schröder, W., Schrödner, R., and Renner, E.: Influence of grid resolution and meteorological forcing on simulated $\mathrm{Eu}-$ ropean air quality: A sensitivity study with the modeling system COSMO-MUSCAT, Atmos. Environ., 53, 110-130, 2012.

Zängl, G., Reinert, D., Rípodas, P., and Baldauf, M.: The ICON (ICOsahedral Non-hydrostatic) modelling framework of DWD and MPI-M: Description of the non-hydrostatic dynamical core, Q. J. Roy. Meteor. Soc., 141, 563-579, https://doi.org/10.1002/qj.2378, 2015. 